NBER WORKING PAPER SERIES

THE TRADE PERFORMANCE OF ASIAN ECONOMIES DURING AND FOLLOWING THE 2008 FINANCIAL CRISIS

\author{
Jing Wang \\ John Whalley \\ Working Paper 16142 \\ http://www.nber.org/papers/w16142 \\ NATIONAL BUREAU OF ECONOMIC RESEARCH \\ 1050 Massachusetts Avenue \\ Cambridge, MA 02138 \\ June 2010
}

We are grateful a semimar group at CIGI for comments, and to Mohan Agarwal, Li Chunding and Shi Xiaojun for discussion. The views expressed herein are those of the authors and do not necessarily reflect the views of the National Bureau of Economic Research.

NBER working papers are circulated for discussion and comment purposes. They have not been peerreviewed or been subject to the review by the NBER Board of Directors that accompanies official NBER publications.

(C) 2010 by Jing Wang and John Whalley. All rights reserved. Short sections of text, not to exceed two paragraphs, may be quoted without explicit permission provided that full credit, including $\odot$ notice, is given to the source. 
The Trade Performance of Asian Economies During and Following the 2008 Financial Crisis Jing Wang and John Whalley

NBER Working Paper No. 16142

June 2010

JEL No. F14

\begin{abstract}
$\underline{\text { ABSTRACT }}$
This paper documents and compares the trade performance of the major Asian economies both during and following the 2008 financial crisis. We consider China, India, Thailand, Malaysia, South Korea, Japan, Singapore and Chinese Taiwan. We access separate country data files giving monthly trade performance for both the import and export sides throughout the crisis. We use these to compare the size, speed and acceleration of trade compression with the onset of the crisis, and the reverse effects on recovery. We do this in aggregate and by product and bilateral trading partner. The data reported show considerable diversity of country experience. Among manufacture exporters China has seen a major decline in trade with a slow recovery, whereas Korea experienced smaller initial impact but a quick rebound. Import impacts are mildest for India and commodity exporters including Malaysia. On the import side, the falls in world oil prices impact sharply on import values. We also compare trade impacts in the 2008 financial crisis with those in the 1930s and the Asian financial crisis. In the 1930s percentage impacts on trade in the first year were similar, but of much longer duration, reducing trade volumes in the US by nearly $80 \%$ by 1933, and placing Germany close to autarchy. In the 1998 Asian crisis trade impacts were much smaller since export markets in the OECD were not affected, but negative growth impacts on affected countries were greater.
\end{abstract}

Jing Wang

Institute of Quantitative \& Technical Economics

Chinese Academy of Social Sciences (CASS).

Beijing China

wj@ cass.org.cn

John Whalley

Department of Economics

Social Science Centre

University of Western Ontario

London, Ontario N6A 5C2 CANADA

and NBER

jwhalley@uwo.ca 


\section{Background and Issues}

In September and October 2008, the world experienced the onset of a major Financial Crisis, triggered in part by a loss of confidence by investors in the value of securitized mortgages in the US during 2007. It also coincided with the reversal of price bubbles in housing, oil, and resource commodities, and resulted in significant stock price declines and exchange rate volatility. These events were followed by a worldwide recession in 2009 with a sharp reduction in world trade and rising unemployment. Although the worldwide crisis seemingly originated in the United States, its effects were felt by all economies around the world. To date there has been no research which compares the speed, severity, and acceleration of both decline in trade and the rebound of Asian economies. This is what we attempt to do here.

We document the trade performance of the Asian economies throughout the crisis. In the preceding two decades many of these had become major manufacturing exporters. The impacts on auto exports for Japan, consumer electronics exports from China, and manufactured exports from Korea were all major. We use official data for key Asian economies, including China, India, Japan, South Korea (referred to as Korea hereinafter), Malaysia, Chinese Taiwan (referred to as Taiwan hereinafter), Thailand and Singapore, and compare and analyse their trade performance during and beyond the crisis.

Comparison of May 2008 and May 2009 shows that monthly exports of China, India, Japan, Korea, Malaysia, Taiwan and Thailand fell by $26.3 \%, 37.1 \%, 49.4 \%$, $15.4 \%, 29.8 \%, 26.6 \%$ and $44.4 \%$ respectively. Monthly imports fell by more by $43.1 \%$, $37.3 \%, 42.7 \%, 24.3 \%, 30.3 \%, 40.3 \%$ and $56.6 \%$ respectively, reflecting in part the oil price decline. Among these countries, Korean trade performed the best, with a smaller drop after the initial onset of the crisis and a quick rebound. Japan's trade was affected most, with a severe and prolonged decline on both the export and import side.

We compare this trade performance both with that of the North American and European economies in the 1930s and with that of the severely impacted Asian economies in the 1997-98 Asian financial crisis. In the 1930s initial year trade impacts were similar in percentage terms, but persisted in the North American and European 
economies for four years or more. Japan in the 1930s, however, had several years of strong export growth, and China also performed much better than North America and Europe. Trade impacts in Asian were more severe than in either Europe or North America, and are more severe in the recent crisis than in the 1997-98 Asian financial crisis, but growth impacts on affected countries were more severe in 1997-98. 


\section{The Overall Trade Performance of the Asian Economies during the Financial}

\section{Crisis}

We first discuss the overall trade performance of the Asian countries (region) during the financial crisis. We consider China, India, South Korea (Korea for short), Japan, Malaysia, Chinese Taiwan, and Thailand for whom monthly data are available for 2008 and 2009, and initial months of 2010. We also consider Singapore, for which there are quarterly data.

Table 1: Percentage Export Growth Rates of Key Asian Economies 2008-10 by Month (Compared with the same month in the previous year, \%)

\begin{tabular}{l|c|c|c|c|c|c|c||c|c|c|c|c|c|c}
\hline & \multicolumn{7}{|c||}{ Y2008 } & \multicolumn{7}{c}{ Y2009 } \\
\hline & CN & IN & JP & KR & MY & CT & TH & CN & IN & JP & KR & MY & CT & TH \\
\hline Jan & 26.6 & 35.8 & 7.7 & 15.6 & 10.4 & 11.8 & 36.1 & -17.5 & -13.6 & -45.7 & -7.3 & -27.7 & -44.1 & -26.5 \\
\hline Feb & 6.4 & 44.1 & 8.7 & 19.8 & 14.6 & 18.3 & 18.6 & -25.7 & -21.5 & -49.4 & 20.9 & -15.9 & -28.6 & -11.6 \\
\hline Mar & 30.6 & 34.1 & 2.2 & 22.1 & 5.5 & 22.7 & 16.3 & -17.1 & -25.1 & -45.5 & 18.5 & -15.7 & -35.8 & -23.2 \\
\hline Apr & 21.8 & 63.0 & 3.9 & 33.5 & 20.8 & 13.9 & 30.0 & -22.6 & -35.0 & -39.1 & 9.3 & -26.5 & -34.3 & -26.1 \\
\hline May & 28.1 & 50.0 & 3.6 & 40.7 & 22.9 & 20.5 & 24.5 & -26.3 & -37.1 & -40.9 & -12.5 & -29.8 & -31.4 & -26.6 \\
\hline Jun & 17.3 & 58.5 & -1.8 & 29.1 & 18.5 & 21.2 & 30.2 & -21.2 & -32.2 & -35.8 & 5.5 & -22.6 & -30.4 & -26.0 \\
\hline Jul & 26.9 & 52.1 & 7.9 & 50.8 & 25.3 & 7.9 & 45.1 & -22.9 & 30. & -36.5 & -3.2 & -22.7 & -24.5 & -25.7 \\
\hline Aug & 21.1 & 40.5 & 0.2 & 30.5 & 10.6 & 18.2 & 15.9 & -23.1 & -27.2 & -36.0 & -4.8 & -20.0 & -24.6 & -18.4 \\
\hline Sep & 21.4 & 26.1 & 1.5 & 52.2 & 14.9 & -1.6 & 20.0 & -15.0 & -13.0 & -30.6 & -0.3 & -24.2 & -12.7 & -8.5 \\
\hline Oct & 19.1 & -3.7 & -7.9 & 49.4 & -2.7 & -8.3 & 3.0 & -13.7 & & -23.2 & -15.4 & 1.7 & -4.6 & -3.0 \\
\hline Nov & -2.2 & -13.5 & -26.8 & 21.5 & -4.8 & -23.3 & -20.9 & -1.2 & & -6.3 & 0.0 & -3.5 & 19.3 & 17.2 \\
\hline Dec & -2.8 & -8.6 & -35.0 & 23.6 & -14.8 & -41.9 & -14.6 & 17.6 & & 12.0 & 10.7 & 18.7 & 46.8 & 26.1 \\
\hline \hline
\end{tabular}

Key: CN - China, IN - India, JP - Japan, KR - Korea, MY - Malaysia, TH - Thailand, CT - Chinese Taiwan.

Source: Authors' calculations. China Customs Statistics, Indian DGCIS (Kolkata), Trade Statistics of Japan, Korean Customs Statistics, Official Portal of Ministry of International Trade and Industry Data (Malaysia), Bank of Thailand, Bureau of Foreign Trade of Taiwan.

Monthly growth rates for exports (compared with the same month in the previous year) are reported for these countries in Table 1. Indian exports grew the fastest and Korean exports grew the second fastest in 2008 pre-crisis. Others showed almost the same performance; Japan was the only country which had export growth rates in single figures in 2008. 
For 2009, the picture is different. Korea was still the best performer among these countries (regions), with negative growth in only four months and a smaller decline than other countries. The worst performer was Japan. With sluggish growth pre-crisis, Japan's exports shrank by over $30 \%$ for ten months, and they were almost half of the previous year in the first quarter of 2009. Taiwan also showed a significant decline from November 2008 and had a decline of over 40\% in two months. Exports from Malaysia showed the same trend as those of Taiwan but with a milder decline both on onset and rebound. China's 2009 performance was slightly better than that of India, Malaysia and Taiwan.

Table 2: Percentage Import Growth Rates of Key Asian Economies 2008-10 by Month (Compared with same month in the previous year, \%)

\begin{tabular}{l|c|c|c|c|c|c|c||c|c|c|c|c|c|c}
\hline & \multicolumn{7}{|c||}{ Y2008 } & \multicolumn{7}{c}{ Y2009 } \\
\hline & CN & IN & JP & KR & MY & CT & TH & CN & IN & JP & KR & MY & CT & TH \\
\hline Jan & 27.5 & 58.1 & 9.5 & 32.6 & 7.2 & 14.7 & 44.2 & -43.1 & -20.2 & -31.8 & -3.7 & -30.3 & -56.6 & -35.5 \\
\hline Feb & 35.1 & 51.4 & 10.7 & 29.4 & 11.1 & 26.0 & 33.3 & -23.8 & -31.3 & -42.7 & 2.4 & -27.6 & -32.1 & -40.3 \\
\hline Mar & 24.8 & 37.6 & 11.4 & 29.6 & 2.8 & 37.5 & 32.4 & -24.9 & -29.6 & -36.4 & -0.7 & -29.1 & -49.7 & -35.1 \\
\hline Apr & 26.6 & 65.0 & 12.2 & 36.3 & 7.9 & 17.7 & 43.2 & -22.8 & -37.3 & -35.5 & -11.2 & -22.5 & -41.2 & -36.3 \\
\hline May & 40.1 & 39.2 & 4.8 & 42.9 & 9.4 & 17.5 & 15.7 & -24.8 & -33.0 & -42.2 & -24.3 & -27.9 & -39.1 & -34.7 \\
\hline Jun & 31.2 & 44.6 & 16.7 & 47.1 & 12.4 & 22.3 & 34.6 & -13.0 & -22.1 & -41.7 & -17.2 & -20.7 & -33.5 & -29.3 \\
\hline Jul & 33.6 & 49.7 & 18.2 & 63.5 & 15.1 & 11.6 & 55.9 & -14.9 & -33.5 & -40.6 & -20.0 & -16.2 & -34.1 & -32.5 \\
\hline Aug & 22.9 & 64.6 & 17.1 & 50.5 & 4.2 & 39.3 & 26.9 & -17.1 & -36.1 & -41.0 & -18.1 & -18.7 & -32.4 & -32.8 \\
\hline Sep & 20.9 & 70.9 & 28.8 & 71.7 & 11.5 & 9.9 & 39.4 & -3.8 & -34.3 & -36.8 & -16.2 & -20.4 & -21.2 & -17.9 \\
\hline Oct & 15.4 & 18.5 & 7.4 & 49.3 & -5.4 & -7.4 & 21.7 & -6.8 & & -35.5 & -20.3 & -2.3 & -6.7 & -17.5 \\
\hline Nov & -18.0 & 6.3 & -14.4 & 26.6 & -8.2 & -13.7 & 2.0 & 26.3 & & -16.7 & -11.7 & 2.2 & 18.0 & -2.2 \\
\hline Dec & -21.3 & -3.3 & -21.5 & 20.0 & -22.5 & -44.6 & -6.5 & 55.6 & & -5.5 & 1.4 & 23.5 & 55.6 & 28.2 \\
\hline \hline
\end{tabular}

Key: CN - China, IN - India, JP - Japan, KR - Korea, MY - Malaysia, TH - Thailand, CT - Chinese Taiwan.

Source: Authors' calculations. China Customs Statistics, Indian DGCIS (Kolkata), Trade Statistics of Japan, Korean Customs Statistics, Official Portal of Ministry of International Trade and Industry Data (Malaysia), Bank of Thailand, Bureau of Foreign Trade of Taiwan.

The growth rates of imports by the same Asian economies are reported in Table 2. Korean imports fell least among those economies (as for exports). Pre-crisis, the 
fastest growth of imports occurred in India and Korea, whereas the lowest growth rates in 2008 were for Malaysia and Japan. Imports by Malaysia and Taiwan started to fall in October 2008, followed by China and Japan one month later, but Korea maintained strong positive export growth for the whole of 2008. Imports of all these economies declined in the first ten months of 2009, and Korean imports declined the least among these economies. Taiwan's imports dropped the most at the beginning of 2009 and those of Japan fell the most in proportional terms in 2009. Except for Korea, country imports seem to follow a pattern whereby the faster the growth pre-crisis, the greater the decline during the crisis. One reason for the decline in imports was falling oil prices in 2009, along with the recession in the real economies. Trade for all economies started to rebound at the end of 2009 and they experienced accelerated recovery. There is a solid rebound shown for 2010 in available data, with Taiwan's imports doubling in January 2010 and China's increasing by over $60 \%$ in the first quarter of 2010 .

Interestingly, the Korean economy more broadly and Korean financial markets experienced less impact in the current financial crisis than in that of 1997-98. As Huh and Nam (2010) note, several factors have contributed to this outcome. One was that Korea in 2008 did not have the problem of non-performing assets that needed to deal with through restructuring processes as in the 1997-98 crisis. Also, policy reactions were more prompt and provided significant resources which stopped the economy's downward spiral during 2008 financial crisis. Also, policy coordination among leading OECD with Asian economies to counter the down turn benefited Korea.

Quarterly growth rates of foreign trade and GDP for Singapore are reported in Table 3. Singapore's trade performance is close to the mean compared with other Asian economies, in both the decline and recovery of growth. Compared with the same period in the previous year pre-crisis, Singapore's real GDP grew by $7.3 \%$ (nominal growth rate was $10.6 \%$ ) in the first quarter of 2008, whereas foreign trade grew by $16.1 \%$ (with exports at $11.5 \%$ and imports at $21.5 \%$ ) at the same time. Total trade started to decline in the last quarter of 2008, GDP began to see negative growth and the overall price level shifted to deflation. Overall trade declined by $28 \%$ in the first quarter of 2009 and Singapore's real GDP fell by 9.4\%. This linkage highlights the 
pronounced impact of the financial crisis on Singapore as an economy highly dependent on foreign trade.

Table 3: Growth Rates of Singapore's Export, Import and GDP During the Financial Crisis (Compared with corresponding period in the previous year, \%)

\begin{tabular}{l|c|c|c|c|c|c|c|c|c|c|c}
\hline & 08Q1 & 08Q2 & 08Q3 & 08Q4 & 09Q1 & 09Q2 & 09Q3 & 09Q4 & Jan10 & Feb10 & Mar10 \\
\hline Export & 11.5 & 13.2 & 11.4 & -12.0 & -27.8 & -25.4 & -20.0 & 4.9 & 37.0 & 19.2 & 29.3 \\
\hline Import & 21.5 & 21.4 & 22.2 & -7.1 & -27.6 & -28.4 & -22.8 & -2.7 & 28.8 & 16.4 & 30.8 \\
\hline Real GDP & 7.3 & 2.8 & 0.1 & -4.2 & -9.4 & -3.1 & 0.6 & 4.0 & & & \\
\hline Nominal GDP & 10.6 & 5.9 & 2.5 & -5.5 & -9.1 & -5.8 & -1.9 & 3.6 & & & \\
\hline
\end{tabular}

Source: Growth rates of trade are authors' calculations based on Statistics Singapore data, GDP data are also taken from Statistics Singapore, http://www.singstat.gov.sg/.

From the data above, we can also see the collapse of 2009 world trade as reflecting a sharp decline in Asian countries' foreign trade in general. For instance, China's foreign trade halted a trend of export expansion in place since 1999. As a result, China's exports dropped by 26\% in May 2009 and imports dropped by $43 \%$ in January 2009 , compared with the same months in 2008. Also, China's share of net global export growth in GDP growth dropped from over 10\% between 2000 and 2007 to $0.8 \%$ in 2008. In the rebound, in March 2010, China's foreign trade was in deficit by US\$7.2 billion, the first since 2004. China's trade balance returned to surplus in April 2010 but with only a US $\$ 1.7$ billion surplus, which is less than $10 \%$ of the earlier sum.

This overall Asian performance can also be seen relative to the wider global picture of sharp trade compression in the crisis. The volume of world exports and imports fell by $23 \%$ and $24 \%$ (in current US\$) respectively in 2009 according to the WTO $(2010)^{1}$ and along with this went substantial variation in trade performance by region and country. On the export side in 2009, oil exporters in Africa saw an export volume fall of $40 \%$ and Russian exports dropped by $36 \%$ owing in large part to falling prices of oil and other primary commodities. Exports by Asian and North American economies fell less than the global average level with drops of $18 \%$ and $21 \%$ respectively.

\footnotetext{
1 WTO press release No. 598, "World Trade 2009, Prospects For 2010: Trade to Expand by 9.5\% in 2010 after a Dismal 2009", 26 March 2010.
} 
Asian export performance shows China and ASEAN dropped by only $16 \%$ and $18 \%$ respectively, which accounts for $56.5 \%$ of total Asian exports. Exports from Korea even increased by $1 \%$ in 2009 , whereas those of Japan fell by $28 \%$. These fell more than the world average. On the import side, imports of Africa, Middle East, and Asia fell by less than the world average by $16 \%, 18 \%$ and $21 \%$ respectively. Imports by Korea and Malaysia dropped by $12 \%$ and $17 \%$, which were smaller than world import drops in percentage terms. Imports by Japan and Taiwan fell by $28 \%$, and those of ASEAN and India fell by $23 \%$ and $21 \%$ in 2009 , which contributed significantly to the decline of Asian imports.

The slightly smaller drop of Asian imports than world imports mainly reflects China's imports (which account for about a third of Asian imports) which only fell by 11\%. Also, China's Southern trade has grown significantly faster than its Northern trade in the past decade (Wang \& Whalley, 2010), and so the smaller compression in trade by Africa, Asia (except Japan) and Latin America partly explains the trade performance of China.

Though Asian trade performance was relatively good for the year 2009, it was affected more severely during the initial impact of the current crisis. Global trade volumes fell by $17.5 \%$ between September 2008 and January 2009 in an episode now termed the "Great Trade Collapse" (Gregory et al., 2010, page 4), and trade volumes of Taiwan and Japan fell by $50 \%$ and $46 \%$ respectively. Even the trade of Korea and China, good trade performers during the crisis, fell by $29 \%$ and $42 \%$ respectively during the same period. Trade in India and Malaysia also fell by over 33\% during the same period.

The constant US\$ world trade volume reduction of $12 \%$ in 2009 is larger than those on the three other occasions this has happened since $1965(-0.2 \%$ in $2001,-2 \%$ in 1982, and $-7 \%$ in 1975). Japan's export fell the most by $24.9 \%$ and was over twice the world average level. World GDP declined by $2.3 \%$ in 2009. GDP of the Commonwealth of Independent States (CIS), Japan and the EU(27) fell by 7.1\%, 5\%, 
and $4.2 \%$ respectively, whereas GDP growth in Africa, the Middle East and Asia remained positive at $1.6 \%, 1.0 \%$ and $0.1 \%$ respectively, and China grew by $8.5 \%$ in 2009.

According to the WTO $(2010)^{1}$ the value of world merchandise trade increased by around $25 \%$ in the first quarter of 2010 over the same period in 2009 , with global exports rising by $27 \%$ and imports rising by $24 \%$.

Why trade compression occurred at such a greater rate than GDP growth during the crises, especially in the early stages, and why the rebound also occurred at an equally high rate, is a puzzle that has been noted by others (Baldwin, 2009), but remains largely unexplained. As we note later, in the 1930s, rates of trade compression also exceeded compression rates for GDP, but persisted for much longer.

\footnotetext{
${ }^{1}$ WTO press release No. 604, "First Quarter of 2010 Sees Trade Value Rise by about 25\%", 2 June 2010.
} 


\section{The Bilateral Trade Performance of Asian Economies in the Crisis}

Next we assess the bilateral trade performance of individual Asian countries with four major trading partners, the US, China, the EU, and ASEAN. Growth rates of trade between the US and Asian countries are reported in Table 4.

Table 4: Growth Rates of US Trade with Key Asian Economies During the Financial Crisis (Compared with same month in the previous year, \%)

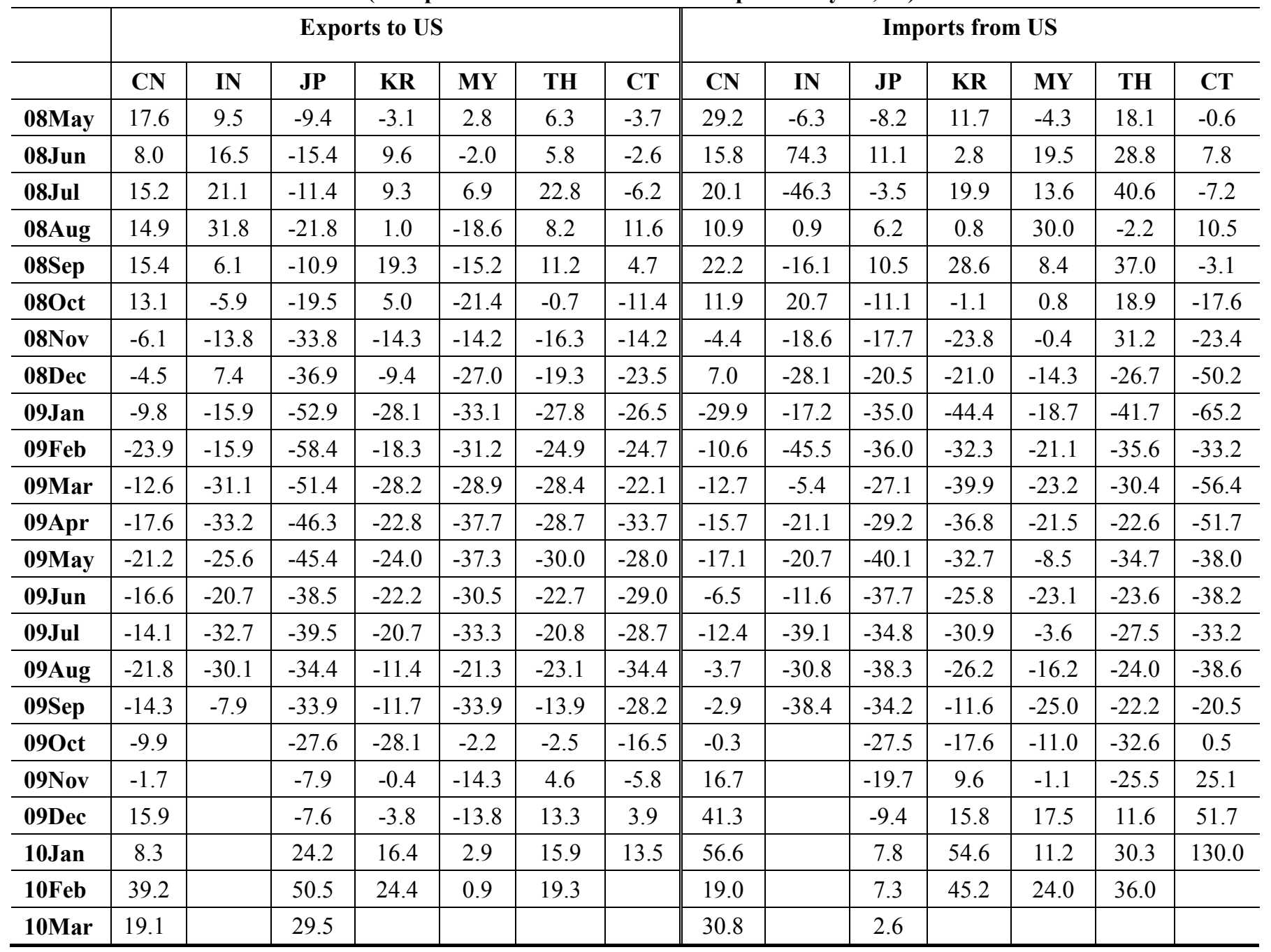

Key: CN - China, IN - India, JP - Japan, KR - Korea, MY - Malaysia, TH - Thailand, CT - Chinese Taiwan.

Source: Authors' calculations.China Customs Statistics, Indian DGCIS (Kolkata), Trade Statistics of Japan, Korea Customs Statistics, Malaysian Official Portal of Ministry of International Trade and Industry figures, Bank of Thailand, Bureau of Foreign Trade of Taiwan.

These data indicate that Japan's exports to the US started declining as early as 
February 2008, and declined the most in the first quarter of 2009, producing less than half the reported exports for the same period in 2008. Asian countries' exports to the US all fell sharply from January 2009 to August 2009, with monthly declines of $23.9 \%$ for China, $58.4 \%$ for Japan, $28.2 \%$ for Korea, and over $30 \%$ for other countries. Thailand and China's exports to the US rebounded at the end of 2009, and followed other countries with a significant rebound in 2010. On the import side, the imports by India, Korea, Thailand and Taiwan of US products declined more than their exports to the US, with monthly declines of $46.3 \%, 44.4 \%, 41.7 \%$ and $65.2 \%$ respectively. China's exports to and imports from the US are similar in trend, but imports show a stronger rebound in 2010 than exports, which contributed to China's trade deficit in March 2010. Similarly to exports, the most severe decline in imports occurred in the first quarter of 2009.

The picture is thus of sharper than average declines in US trade with some Asian countries ( Japan and Korea), and smaller declines with other countries (China).

The growth rates of other Asian countries' trade with China during the crisis are reported in Table 5. Exports by India, Korea, Thailand and Taiwan to China fell sharply in the last quarter of 2008, and declined more than exports to the US in percentage terms. Japan's exports to China declined less than those to the US during the crisis, which is slightly better than Japan's total export performance. All countries' exports to China rebounded strongly from the end of 2009. These countries' imports from China fell sharply in the first quarter of 2009 , lagged a couple of months more than exports to China, and started to rebound from the end of 2009, almost synchronously with exports. The rebound speed for imports is significantly lower than that for exports, which indicates that China's large market for foreign goods contributed to the recovery of neighborig trade. 
Table 5: Growth Rates of China' Trade with Key Asian Economies During the Financial Crisis

(Compared with same month in the previous year, \%)

\begin{tabular}{|c|c|c|c|c|c|c|c|c|c|c|c|c|}
\hline & \multicolumn{6}{|c|}{ Exports to China } & \multicolumn{6}{|c|}{ Imports from China } \\
\hline & IN & $\mathbf{J P}$ & KR & MY & TH & CT & IN & $\mathbf{J P}$ & KR & MY & TH & CT \\
\hline 08May & 38.5 & 12.1 & 35.3 & 96.3 & 13.1 & 38.1 & 60.0 & -3.9 & 31.2 & -14.8 & 21.9 & 23.1 \\
\hline 08Jun & 31.2 & 4.8 & 33.1 & 36.3 & 21.4 & 49.7 & 39.9 & 0.3 & 33.9 & -2.4 & 31.7 & 27.4 \\
\hline 08Jul & 41.7 & 16.4 & 30.1 & 74.1 & 37.8 & 16.4 & 49.2 & 5.2 & 44.1 & 10.8 & 50.8 & 13.7 \\
\hline 08Aug & 15.8 & 8.6 & 19.3 & 30.0 & 1.9 & 24.2 & 31.7 & -4.6 & 37.3 & -0.8 & 18.9 & 35.8 \\
\hline 08Sep & -23.5 & 1.6 & 15.0 & 14.6 & 6.7 & -13.9 & 45.1 & 16.1 & 47.2 & 4.3 & 35.8 & 10.4 \\
\hline 08Oct & -51.8 & -1.0 & -3.5 & -8.6 & 4.3 & -19.7 & -2.6 & 2.8 & 8.4 & 1.5 & 14.2 & -2.0 \\
\hline $08 \mathrm{Nov}$ & -64.5 & -24.5 & -33.3 & -26.5 & -36.5 & -42.1 & -3.6 & -12.0 & -14.2 & -7.1 & -2.1 & -9.4 \\
\hline 08Dec & -6.9 & -35.5 & -35.4 & -29.2 & -40.1 & -57.1 & 17.0 & -12.4 & -22.6 & -26.4 & -10.8 & -31.5 \\
\hline 09Jan & -26.7 & -45.2 & -38.6 & -33.7 & -40.1 & -63.5 & -13.6 & -16.2 & -35.0 & -23.5 & -26.2 & -51.6 \\
\hline 09Feb & -31.1 & -39.7 & -13.6 & 7.8 & -30.4 & -32.6 & -15.0 & -40.8 & -30.8 & -29.7 & -40.4 & -22.0 \\
\hline 09Mar & -40.8 & -31.6 & -22.4 & 23.6 & -14.2 & -44.7 & -15.8 & -20.6 & -29.8 & -15.4 & -24.6 & -33.2 \\
\hline 09Apr & -27.3 & -26.0 & -19.2 & -9.0 & -13.4 & -34.6 & -27.6 & -21.7 & -39.2 & -24.4 & -20.5 & -39.2 \\
\hline 09May & -41.3 & -29.7 & -25.6 & -28.0 & -11.0 & -32.4 & -32.7 & -31.9 & -42.1 & -0.8 & -30.7 & -39.2 \\
\hline 09Jun & -21.7 & -23.7 & -16.1 & -10.1 & -3.6 & -35.8 & -9.4 & -26.1 & -35.6 & -6.8 & -27.1 & -30.8 \\
\hline 09Jul & -29.6 & -26.5 & -12.9 & -16.1 & -21.6 & -21.5 & -22.0 & -26.5 & -39.0 & -14.2 & -30.3 & -31.4 \\
\hline 09Aug & -5.0 & -27.6 & -10.3 & -9.6 & 1.2 & -18.6 & -12.2 & -23.3 & -37.5 & -14.9 & -15.8 & -31.6 \\
\hline 09Sep & 12.8 & -13.9 & 3.4 & 19.2 & 4.5 & 2.1 & -20.6 & -24.5 & -30.9 & -12.7 & -13.6 & -7.8 \\
\hline 09Oct & & -14.4 & 9.5 & 46.4 & 2.1 & 10.5 & & -26.5 & -25.4 & -12.8 & 5.5 & -6.1 \\
\hline 09Nov & & 7.8 & 54.1 & 56.2 & 77.1 & 56.0 & & -11.1 & -3.9 & 21.1 & 20.2 & 23.0 \\
\hline 09Dec & & 42.7 & 93.1 & 103.9 & 117.6 & 96.5 & & -5.8 & 20.9 & 28.8 & 40.8 & 42.4 \\
\hline 10Jan & & 80.0 & 98.2 & 136.8 & 94.3 & 187.8 & & -2.3 & 19.3 & 19.2 & 42.5 & 100.5 \\
\hline $10 \mathrm{Feb}$ & & 47.6 & 43.1 & 39.8 & 75.7 & & & 54.5 & 31.6 & 32.7 & 97.8 & \\
\hline 10Mar & & 47.5 & & & & & & 5.5 & & & & \\
\hline
\end{tabular}

Key: IN - India, JP - Japan, KR - Korea, MY - Malaysia, TH - Thailand, CT - Chinese Taiwan.

Source: Authors' calculations. Indian DGCIS (Kolkata), Trade Statistics of Japan, Korean Customs Statistics, Malaysian Official Portal of Ministry of International Trade and Industry, Bank of Thailand, Bureau of Foreign Trade of Taiwan.

Growth rates of trading by China, India, Japan and Thailand with the EU are reported in Table 6. China's and India's trade with the EU grew rapidly on both the export and import side. Also, imports by Thailand of EU products increased faster before the financial crisis. The trade of China, India and Thailand with the EU began to fall from the end of 2008 (imports of Thailand from the EU fell from January 2009) and declined sharply during the first half of 2009. From the end of 2009, trade between China and the EU showed a strong rebound. Similarly to trade with the US, Japan's 
trade with the EU shrank the most among the Asian economies during the financial crisis. Exports by Japan to the EU grew by $10.6 \%$ in January 2008 ; then the growth abated gradually before turning negative from April 2008 onwards. Growth rates of imports by Japan from the EU fluctuated between $-10 \%$ and $6 \%$ during the first nine months, then declined sharply and continuously for sixteen months.

Table 6: Growth Rates of EU's Trade with Key Asian Economies During the Financial Crisis (Compared with same month in the previous year, \%)

\begin{tabular}{|c|c|c|c|c|c|c|c|c|}
\hline & \multicolumn{4}{|c|}{ Exports to EU } & \multicolumn{4}{|c|}{ Imports from $\mathbf{E U}$} \\
\hline & $\mathrm{CN}$ & IN & $\mathbf{J P}$ & TH & $\mathbf{C N}$ & IN & JP & TH \\
\hline 08May & 35.1 & 58.4 & -1.1 & 14.2 & 43.6 & 14.5 & -7.9 & 26.3 \\
\hline 08Jun & 25.3 & 37.2 & -11.2 & 6.6 & 31.3 & 42.2 & 1.5 & 6.7 \\
\hline 08Jul & 27.6 & 29.2 & 4.1 & 19.2 & 33.0 & 16.9 & -6.2 & 43.4 \\
\hline 08Aug & 21.9 & 28.1 & -3.5 & 8.4 & 18.2 & 50.0 & -7.9 & 13.0 \\
\hline 08Sep & 20.9 & 19.1 & -9.0 & 13.2 & 17.0 & 68.9 & 5.4 & 31.6 \\
\hline 08Oct & 16.0 & 0.5 & -17.2 & 3.4 & 21.7 & -9.8 & -11.6 & 2.8 \\
\hline 08Nov & -0.4 & -16.4 & -30.9 & -19.8 & -8.7 & -9.3 & -20.7 & 6.1 \\
\hline 08Dec & -2.9 & 13.6 & -41.8 & -17.5 & -6.1 & -8.7 & -16.1 & 9.9 \\
\hline 09Jan & -17.5 & -4.2 & -47.4 & -27.7 & -21.7 & 6.1 & -23.4 & -19.2 \\
\hline 09Feb & -30.2 & -8.1 & -54.7 & -29.3 & -4.9 & -25.0 & -29.7 & -8.7 \\
\hline 09Mar & -20.2 & -23.0 & -56.1 & -35.3 & -17.4 & -17.4 & -32.8 & -29.9 \\
\hline 09Apr & -27.5 & -39.6 & -45.3 & -34.3 & -17.2 & -32.7 & -31.0 & -29.4 \\
\hline 09May & -29.2 & -36.7 & -45.4 & -34.8 & -18.4 & -37.8 & -28.7 & -24.7 \\
\hline 09Jun & -23.0 & -31.6 & -41.3 & -27.4 & 2.1 & -25.0 & -25.9 & -16.0 \\
\hline 09Jul & -26.0 & -28.2 & -45.8 & -24.0 & -7.4 & -23.3 & -30.9 & -14.9 \\
\hline 09Aug & -26.6 & -26.7 & -45.9 & -29.1 & -6.7 & -30.0 & -24.1 & -11.7 \\
\hline 09Sep & -17.4 & -16.8 & -38.6 & -20.4 & 7.6 & -41.4 & -23.0 & -11.0 \\
\hline 09Oct & -14.9 & & -29.0 & -11.7 & -5.4 & & -21.8 & -9.4 \\
\hline 09Nov & -8.0 & & -16.0 & 6.0 & 22.7 & & -7.9 & 0.5 \\
\hline 09Dec & 10.2 & & 1.4 & 16.3 & 27.6 & & -6.3 & -2.6 \\
\hline 10Jan & 17.7 & & 11.2 & 13.2 & 46.1 & & -1.4 & 8.4 \\
\hline $10 \mathrm{Feb}$ & 60.1 & & 19.7 & 28.7 & 21.5 & & 7.3 & 20.2 \\
\hline 10Mar & 24.6 & & 26.7 & & 56.8 & & 13.4 & \\
\hline 10Apr & 28.5 & & & & 40.8 & & & \\
\hline
\end{tabular}

Key: CN - China, IN - India, JP - Japan, TH - Thailand.

Source: Authors' calculations. China Customs Statistics, Indian DGCIS (Kolkata), Trade Statistics of Japan, Bank of Thailand.

The growth rates of trade involving China, India, Japan and Thailand with ASEAN are reported in Table 7. The trade of Japan with ASEAN grew the most slowly 
before the crisis. The proportional decline in exports by India and Japan to ASEAN was approximately the same during the crisis. Exports by India to ASEAN grew at a high rate during the first half of 2008 , with a growth rate of $142.5 \%$ in June 2008 , but started declining sharply from October 2008 onwards. Imports by India from ASEAN grew the most rapidly before the crisis and fell the least during the crisis among these countries. The trade of Thailand with other ASEAN countries grew the second most rapidly before the crisis, and dropped less than Japan and India on the export side and less than Japan and China on the import side.

Table 7: Growth Rates of ASEAN's Trade with Key Asian Economies During the Financial Crisis (Compared with same month in the previous year, \%)

\begin{tabular}{|c|c|c|c|c|c|c|c|c|}
\hline & \multicolumn{4}{|c|}{ Export to ASEAN } & \multicolumn{4}{|c|}{ Import from ASEAN } \\
\hline & $\mathbf{C N}$ & $\mathbf{I N}$ & JP & TH & $\mathbf{C N}$ & IN & JP & TH \\
\hline 08May & 28.4 & 99.9 & 11.9 & 37.5 & 31.2 & 60.0 & -2.8 & 0.5 \\
\hline 08Jun & 14.6 & 142.5 & 6.2 & 63.2 & 19.3 & 39.9 & 13.2 & 38.1 \\
\hline 08Jul & 30.8 & 101.2 & 18.0 & 70.1 & 26.9 & 49.2 & 7.1 & 31.9 \\
\hline 08Aug & 27.3 & 30.7 & 11.0 & 15.6 & 8.8 & 31.7 & 17.8 & 9.1 \\
\hline 08Sep & 24.2 & 29.1 & 5.7 & 32.4 & 2.7 & 45.1 & 25.9 & 25.7 \\
\hline 08Oct & 21.9 & -12.8 & 3.7 & -3.2 & 0.2 & -2.6 & 10.9 & 10.2 \\
\hline 08Nov & -2.6 & -30.7 & -16.0 & -28.1 & -25.4 & -3.6 & -9.5 & -17.4 \\
\hline 08Dec & -11.8 & -28.2 & -28.3 & -21.3 & -31.8 & 17.0 & -14.7 & -2.4 \\
\hline 09Jan & -22.0 & 29.3 & -41.4 & -35.8 & -49.7 & -13.6 & -29.6 & -22.9 \\
\hline 09Feb & -27.7 & -35.6 & -52.0 & -27.6 & -26.3 & -15.0 & -40.9 & -35.2 \\
\hline 09Mar & -18.1 & -46.8 & -43.8 & -31.2 & -25.5 & -15.8 & -36.7 & -18.0 \\
\hline 09Apr & -20.2 & -8.5 & -40.8 & -30.8 & -26.1 & -27.6 & -34.1 & -39.0 \\
\hline 09May & -15.5 & -40.6 & -40.7 & -31.0 & -27.1 & -32.7 & -42.0 & -15.5 \\
\hline 09Jun & -14.5 & -45.0 & -32.6 & -36.5 & -13.0 & -9.4 & -38.4 & -26.1 \\
\hline 09Jul & -17.4 & -26.4 & -30.9 & -29.2 & -12.8 & -22.0 & -37.1 & -21.7 \\
\hline 09Aug & -12.7 & -32.0 & -30.8 & -17.6 & -15.6 & -12.2 & -38.9 & -22.2 \\
\hline 09Sep & 1.2 & -6.4 & -24.7 & -16.7 & 1.7 & -20.6 & -37.8 & -10.3 \\
\hline 09Oct & -1.9 & & -20.4 & -2.6 & 2.6 & & -37.0 & -3.3 \\
\hline 09Nov & 20.8 & & -4.5 & 22.5 & 45.1 & & -20.7 & 6.0 \\
\hline 09Dec & 50.1 & & 17.0 & 44.3 & 78.8 & & -12.6 & 30.5 \\
\hline 10Jan & 52.8 & & 55.9 & 64.3 & 118.7 & & 9.9 & 24.4 \\
\hline $10 \mathrm{Feb}$ & 53.1 & & 73.4 & 65.3 & 51.1 & & 21.1 & \\
\hline 10Mar & 36.8 & & 63.5 & & 72.1 & & 24.0 & \\
\hline 10Apr & 42.6 & & & & 61.5 & & & \\
\hline
\end{tabular}

Key: CN - China, IN - India, JP - Japan, TH - Thailand.

Source: Authors' calculations. China Customs Statistics, Indian DGCIS (Kolkata), Trade Statistics 
of Japan, Bank of Thailand.

Quarterly growth rates of trade between Singapore and its major partners are reported in Table 8. On the export side, Singapore's exports to China dropped the least during the crisis and rebounded the most. On the import side, imports from the EU grew the fastest in 2008 and declined the least in 2009 among these partners. Exports to the US and imports from Japan fell the most in 2009.

Table 8: Growth Rates of Singapore's Trade with Major Partners During the Financial Crisis (Compared with corresponding quarter in the previous year, \%)

\begin{tabular}{l|c|c|c|c|c||c|c|c|c|c}
\hline & \multicolumn{9}{|c||}{ Exports } & \multicolumn{5}{c}{ Imports } \\
\hline & CN & ID & JP & US & EU & CN & ID & JP & US & EU \\
\hline 08Q1 & -1.0 & 15.8 & 18.3 & -11.5 & 0.4 & 0.6 & 13.7 & 17.5 & 8.9 & 29.0 \\
\hline 08Q2 & 10.5 & 27.8 & 17.2 & -14.8 & 11.1 & -3.8 & 13.4 & 19.3 & 9.2 & 17.8 \\
\hline 08Q3 & 10.9 & 28.0 & 5.6 & -17.7 & 3.5 & 11.7 & 24.3 & 16.6 & 14.3 & 18.2 \\
\hline 08Q4 & -17.6 & -14.3 & -6.3 & -17.6 & -10.6 & -11.7 & -1.6 & -1.0 & 2.3 & -8.6 \\
\hline 09Q1 & -24.1 & -28.0 & -32.1 & -39.1 & -26.1 & -29.3 & -9.9 & -35.8 & -19.7 & -19.9 \\
\hline 09Q2 & -21.8 & -34.3 & -34.9 & -27.1 & -32.2 & -23.7 & -31.2 & -33.4 & -29.5 & -14.6 \\
\hline 09Q3 & -20.1 & -28.8 & -19.9 & -19.5 & -27.6 & -25.6 & -28.2 & -26.8 & -22.1 & -12.4 \\
\hline 09Q4 & 20.7 & -3.0 & -6.8 & -6.2 & -5.8 & -3.9 & 7.5 & -5.9 & -14.7 & 5.4 \\
\hline
\end{tabular}

Key: CN - China, ID - Indonesia, JP - Japan, US - United States, EU - European Union.

Source: Authors' calculations based on data from Statistics Singapore, http://www.singstat.gov.sg/.

The overall picture from the above is that of a severe impact of the financial crisis on the trade of Asian countries which affected most trading partners. The most severe impact caused by the recession has seemingly been on US imports from Japan and China, but from the end of 2009, the trade of all these Asian economies shows a rebound, and the strongest rebound occurs in trade between ASEAN and China, which suggests the importance of geography in trade recovery. 


\section{Comparing the Trade Performance of Asian Economies by Major Product}

\section{Group and Type of Trade}

We next turn to the trade performance of major export product groups involving Asian countries during and following the crisis. As well as look at type of trade (processing / non-processing) and type of enterprise in China's case. Data are presented in Tables 9 to 15 . Performance in terms of total trade varies by country and type of trade, but more by product group than by trade type.

Table 9: Export Growth Rates of Key Asian Economies by Major Product Group During and Following the Crisis (Compared with same month in the previous year, \%)

\begin{tabular}{|c|c|c|c|c|c|c|c|c|c|c|c|c|c|c|c|}
\hline & \multicolumn{5}{|c|}{ Manufactures } & \multicolumn{5}{|c|}{ Textile, Yard, Clothing and Related } & \multicolumn{5}{|c|}{ Electronics } \\
\hline & $\mathbf{C N}$ & IN & $\mathbf{J P}$ & KR & TH & $\mathbf{C N}$ & IN & JP & KR & TH & $\mathrm{CN}$ & IN & $\mathbf{J P}$ & KR & TH \\
\hline 08Мау & 27.4 & 57.5 & 1.9 & 34.2 & 24.8 & 10.7 & 14.0 & 7.0 & 11.5 & 4.8 & 38.1 & 37.5 & 2.3 & 32.5 & 5.7 \\
\hline 08Jun & 15.9 & 56.4 & -3.9 & 21.7 & 28.9 & -2.2 & 22.3 & -2.7 & 3.4 & -1.6 & 31.0 & 65.7 & -4.6 & 21.1 & 8.5 \\
\hline 08Jul & 25.7 & 46.4 & 6.1 & 42.1 & 42.6 & 9.4 & 12.4 & 3.4 & 23.9 & 15.3 & 34.9 & 46.6 & 2.2 & 21.7 & 13.5 \\
\hline 08Aug & 20.3 & 40.4 & -1.9 & 25.2 & 13.6 & 4.2 & 1.1 & -0.7 & 5.6 & -2.8 & 26.4 & 63.9 & -4.9 & 8.6 & 1.4 \\
\hline 08Sep & 20.4 & 32.4 & 0.3 & 46.2 & 17.9 & 4.0 & -3.1 & 0.7 & 29.6 & 4.0 & 29.7 & 51.6 & -5.7 & 30.2 & 9.9 \\
\hline 08Oct & 18.9 & 5.5 & -8.6 & 46.9 & 1.8 & 14.2 & -8.4 & -7.7 & 41.7 & 2.6 & 19.1 & 40.4 & -10.6 & 26.1 & -5.9 \\
\hline 08Nov & -2.3 & -2.7 & -27.0 & 21.5 & -20.1 & 4.2 & -23.9 & -26.0 & 19.4 & -14.4 & 22.4 & 27.6 & -29.8 & -0.7 & -24.2 \\
\hline 08Dec & -3.2 & 19.2 & -35.4 & 25.9 & -12.6 & 12.3 & -4.2 & -40.3 & 34.4 & -5.8 & 17.3 & 6.6 & -39.5 & -5.2 & -28.8 \\
\hline 09Jan & -17.4 & 0.4 & -45.8 & -7.7 & -25.1 & 1.0 & -24.5 & -44.9 & -2.5 & -10.9 & -4.6 & 0.2 & -47.3 & -12.9 & -37.7 \\
\hline 09Feb & -25.9 & -13.2 & -49.7 & 22.7 & -10.0 & -33.1 & -23.6 & -45.1 & 22.2 & -15.0 & -9.9 & 17.2 & -49.9 & 15.8 & -33.8 \\
\hline 09Mar & -17.1 & -17.0 & -45.8 & 21.4 & -22.2 & 3.5 & -19.1 & -41.4 & 21.6 & -15.2 & -26.9 & 12.6 & -43.9 & 10.7 & -28.5 \\
\hline 09Apr & -22.5 & -31.0 & -39.3 & 12.5 & -24.8 & -11.4 & -32.5 & -31.6 & 15.4 & -17.4 & -24.6 & -20.3 & -33.9 & 10.7 & -22.8 \\
\hline 09May & -25.9 & -35.1 & -40.6 & -8.5 & -25.7 & -14.2 & -23.5 & -37.8 & -8.8 & -19.8 & -21.2 & -32.6 & -36.2 & 1.7 & -24.8 \\
\hline 09Jun & -20.6 & -24.8 & -35.5 & 10.8 & -25.1 & -9.7 & -11.1 & -25.8 & 7.0 & -12.9 & -23.8 & -29.8 & -31.6 & 6.5 & -20.4 \\
\hline 09Jul & -22.5 & -23.0 & -36.1 & 2.4 & -24.0 & -12.0 & -7.9 & -20.5 & 4.2 & -9.4 & -23.8 & -35.9 & -30.8 & 9.0 & -12.7 \\
\hline 09Aug & -23.0 & -25.8 & -35.3 & -1.6 & -16.3 & -14.6 & -6.9 & -19.4 & -2.6 & -18.1 & -19.3 & -35.7 & -30.7 & 9.1 & -12.3 \\
\hline 09Sep & -14.8 & -12.8 & -30.7 & 4.2 & -6.6 & -6.6 & -6.7 & -13.9 & 7.3 & -13.7 & -18.5 & -39.7 & -27.7 & 4.3 & -8.5 \\
\hline 09Oct & & & -23.0 & -14.5 & -2.0 & & & -0.8 & -22.0 & -8.2 & -18.4 & -41.9 & -21.4 & -11.4 & 4.1 \\
\hline 09Nov & & & -6.2 & 0.1 & 14.9 & & & 18.6 & -10.4 & -3.3 & -7.9 & -24.0 & -5.1 & 11.8 & 24.8 \\
\hline 09Dec & & & 11.9 & 10.3 & 21.9 & & & 49.4 & -1.6 & 9.4 & & & 18.9 & 32.6 & 34.7 \\
\hline 10Jan & & & 40.7 & 25.2 & 27.5 & & & 74.4 & 12.1 & 5.6 & & & 48.7 & 27.7 & 51.3 \\
\hline $10 \mathrm{Feb}$ & & & 45.7 & 7.2 & 21.3 & & & 73.8 & -4.6 & 12.5 & & & 45.9 & 5.0 & 50.9 \\
\hline 10Mar & & & 44.3 & & & & & 69.6 & & & & & 42.9 & & \\
\hline
\end{tabular}

Key: CN - China, IN - India, JP - Japan, KR - Korea, TH - Thailand.

Source: Authors' calculations. China Customs Statistics, Indian DGCIS (Kolkata), Trade Statistics of Japan, Korean Customs Statistics, Bank of Thailand.

In Table 9, growth rates for China's export of manufactured goods are almost the 
same as for China's total exports, since manufacture accounts for over $90 \%$ of China's total exports. Japan's exports of manufactures increased slowly during the first half of 2008 , but experienced a sharp decline with a fall of more than $35 \%$ for ten consecutive months. They showed a rapid rebound in 2010. Korean exports of manufactures grew considerably during the whole of 2008, then experienced a slight recession in the first half of 2009 before resuming growth, interrupted intermittently by months of negative growth. India and Thailand both experienced fast expansion of export of manufactures before October 2008, which then fell sharply as the crisis hit. The faster growth of India's trade before the crisis and its sharp decline during the crisis suggest an inverted relationship.

For textile, yarns and clothing, exports by India grew faster than for China and Thailand pre-crisis, but fell more sharply during the crisis. Exports by China declined the least. For exports of electronics, Japan and Korea show a different picture. As with other product groups, Japan's exports of electronics declined first and sharply during the crisis, whereas Korean exports only declined slightly in the three months pre- and post-crisis. For Korea and China, this difference reflects the less severe impact of the crisis on the competitiveness of Korean exports.

Table 10 reports Asian countries' imports during the crisis, reporting growth rates of imports by product group. These data reflect the situation of the real, underlying, economies. For oil, imports by these countries all grew rapidly before October 2008, then fell sharply (except for Korea). The global oil price fluctuations influenced all of these countries' trade, the smaller decline in Korean demand for oil reflecting a weaker impact of the crisis on the Korean economy.

For trade in other minerals, India experienced the most rapid growth pre-crisis and the sharpest decline during the crisis. For base metals and related products, Korean imports grew the most rapidly in 2008 and fell sharply in 2009, whereas Japan's grew the most slowly pre-crisis and dropped the most post-crisis. China's imports of base metals dropped considerately in the crisis and started to rebound beginning in May 2009, following China's stimulus package. This is almost two quarters (i.e. six months) 
ahead of the rebound in other countries' imports of base metals.

Table 10: Import Growth Rates of Key Asian Economies by Major Product Group During and Following the Crisis (Compared with same month in the previous year, \%)

\begin{tabular}{|c|c|c|c|c|c|c|c|c|c|c|c|c|c|c|c|}
\hline & \multicolumn{5}{|c|}{ Oil } & \multicolumn{5}{|c|}{ Minerals (Exclude Oil) } & \multicolumn{5}{|c|}{ Base Metals } \\
\hline & $\mathbf{C N}$ & IN & $\mathbf{J P}$ & $\mathbf{K R}$ & TH & $\mathbf{C N}$ & IN & $\mathbf{J P}$ & $\mathbf{K R}$ & TH & $\mathbf{C N}$ & IN & $\mathbf{J P}$ & KR & TH \\
\hline 08May & 106.0 & 84.8 & 46.8 & 72.5 & 2.1 & 85.4 & 232.0 & -22.2 & 35.8 & 53.3 & 17.5 & 22.4 & -4.4 & 52.2 & 29.2 \\
\hline 08Jun & 92.6 & 71.8 & 51.7 & 90.6 & 70.3 & 73.3 & 241.5 & 5.6 & 25.1 & 96.9 & 2.8 & 9.8 & 5.0 & 44.6 & 51.9 \\
\hline 08Jul & 88.9 & 126.3 & 68.7 & 113.5 & 98.9 & 74.6 & 55.3 & -13.4 & 58.6 & 173.4 & 17.7 & 30.9 & 11.2 & 80.5 & 82.6 \\
\hline 08Aug & 106.4 & 85.8 & 62.7 & 104.3 & 44.3 & 70.9 & 77.3 & 4.4 & 31.0 & 39.7 & 7.2 & 11.9 & 4.2 & 68.1 & 36.0 \\
\hline 08Sep & 72.3 & 64.8 & 62.3 & 99.7 & 40.5 & 67.7 & 72.4 & 15.9 & 77.7 & 60.4 & 13.4 & 46.5 & 24.2 & 115.4 & 72.4 \\
\hline 08Oct & 58.4 & 11.7 & 23.2 & 72.0 & 24.1 & 41.0 & -21.7 & 3.8 & 89.3 & 85.5 & 13.1 & 48.3 & 6.5 & 61.6 & 47.9 \\
\hline 08Nov & -15.1 & -8.2 & -34.8 & 44.4 & -14.3 & -11.6 & -19.8 & -8.8 & 60.0 & 21.8 & -21.7 & 8.6 & -11.0 & 39.1 & 0.1 \\
\hline 08Dec & -31.9 & -32.9 & -52.2 & 20.8 & 3.7 & -27.1 & 1.2 & -18.3 & 37.2 & 16.9 & -19.0 & 4.7 & -18.2 & 20.2 & 0.6 \\
\hline 09Jan & -56.4 & -46.8 & -64.5 & 6.5 & -53.9 & -51.0 & -41.0 & -32.8 & -5.9 & -37.4 & -42.2 & -5.7 & -29.6 & -10.0 & -45.8 \\
\hline 09Feb & -54.8 & -49.8 & -65.0 & -1.7 & -58.5 & -38.9 & -45.1 & -47.1 & -0.3 & -65.2 & -18.1 & -19.4 & -52.4 & -16.3 & -55.9 \\
\hline 09Mar & -54.0 & -54.0 & -64.7 & -11.7 & -42.0 & -37.9 & -53.8 & -48.1 & -8.8 & -27.4 & -14.8 & -23.8 & -49.5 & -4.5 & -51.7 \\
\hline 09Apr & -45.5 & -46.9 & -58.1 & -25.5 & -56.1 & -33.3 & -82.2 & -43.0 & 40.8 & 118.3 & -1.7 & -36.8 & -59.6 & -29.7 & -47.5 \\
\hline 09May & -49.9 & -49.5 & -62.7 & -42.0 & -28.8 & -38.0 & -77.7 & -39.5 & -6.9 & 146.8 & 4.0 & -35.9 & -64.6 & -42.8 & -56.9 \\
\hline 09Jun & -45.3 & -34.8 & -63.4 & -38.9 & -32.9 & -29.5 & -70.7 & -54.3 & 1.8 & -47.2 & 27.8 & -13.5 & -62.6 & -35.0 & -60.1 \\
\hline 09Jul & -34.5 & -42.5 & -58.2 & -37.6 & -45.8 & -24.0 & -28.2 & -37.4 & -18.7 & -53.4 & 9.3 & -25.7 & -59.7 & -40.7 & -58.1 \\
\hline 09Aug & -44.1 & -39.9 & -60.8 & -33.2 & -51.3 & -32.4 & -48.6 & -34.8 & -14.0 & -40.8 & 7.8 & -10.9 & -56.0 & -39.8 & -48.2 \\
\hline 09Sep & -27.6 & -31.5 & -50.0 & -32.8 & 0.4 & -17.2 & -50.7 & -46.3 & -24.8 & -20.6 & 21.6 & -33.7 & -54.6 & -32.5 & -38.2 \\
\hline 09Oct & -18.6 & & -51.2 & -21.7 & -21.2 & & & -42.8 & -16.2 & -38.6 & & & -50.0 & -33.1 & -24.3 \\
\hline 09Nov & 25.5 & & -8.7 & -26.5 & 4.0 & & & -26.6 & -23.2 & -1.0 & & & -32.5 & -21.6 & 1.6 \\
\hline 09Dec & 90.6 & & 28.9 & -2.7 & 18.2 & & & -6.4 & -6.4 & 19.2 & & & -30.7 & -1.7 & 21.9 \\
\hline 10Jan & 116.4 & & 82.7 & 1.6 & 55.7 & & & 21.6 & 26.7 & 53.0 & & & -6.8 & 4.8 & 56.6 \\
\hline $10 \mathrm{Feb}$ & 133.5 & & 71.9 & 13.8 & 50.7 & & & 36.6 & 29.0 & 149.7 & & & 39.2 & 20.2 & 128.7 \\
\hline 10Mar & & & 68.9 & & & & & 54.9 & & & & & 37.4 & & \\
\hline
\end{tabular}

Key: CN - China, IN - India, JP - Japan, KR - Korea, TH - Thailand.

Source: Authors' calculations. China Customs Statistics, Indian DGCIS (Kolkata), Trade Statistics of Japan, Korean Customs Statistics, Bank of Thailand.

Quarterly growth rates of Singapore's trade in major product groups are reported in Table 11. On the export side, exports of oil grew fastest pre-crisis and dropped the most in proportion term during the crisis. Exports of chemicals fell first from the beginning of 2008 and showed a strong rebound in the last quarter of 2009. On the import side, imports of iron and steel grew the fastest in 2008 , but fell rapidly in 2009. Imports of crude materials (excluding oil) of Singapore saw positive growth in the two years with only a slight drop of $2.4 \%$ in the last quarter of 2009. 
Table 11: Growth Rates of Singapore's Trade by Major Product Group During the Financial Crisis (over corresponding period in the previous year, \%)

\begin{tabular}{|c|c|c|c|c|c|c|c|c|c|c|c|}
\hline & \multicolumn{5}{|c|}{ Export } & \multicolumn{6}{|c|}{ Import } \\
\hline & 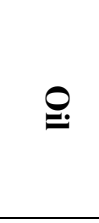 & 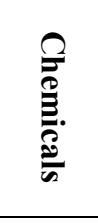 & 胥 & 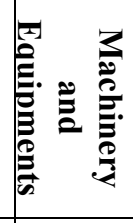 & $\begin{array}{l}\text { 멓 } \\
\frac{2}{2} \\
\frac{0}{8} \\
0\end{array}$ & $\stackrel{\rho}{\varrho}$ & 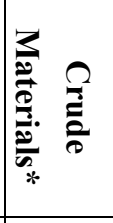 & 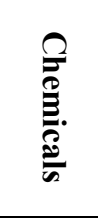 & 苞 & 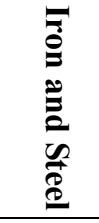 & 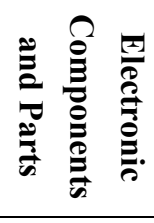 \\
\hline 08Q1 & 52.6 & -4.8 & 2.2 & 3.4 & 2.7 & 4.0 & 29.0 & 7.7 & 13.0 & 20.2 & 0.9 \\
\hline 08Q2 & 53.4 & -6.5 & 15.8 & 1.7 & 2.3 & -3.8 & 12.0 & -2.4 & 16.8 & 16.5 & -2.7 \\
\hline 08Q3 & 77.4 & -9.3 & 4.6 & -1.6 & -1.0 & 16.0 & 20.9 & 9.3 & 21.1 & 73.9 & -1.2 \\
\hline $08 \mathrm{Q} 4$ & -10.0 & -30.8 & -13.5 & -11.0 & -17.3 & 18.8 & 13.8 & -16.3 & 5.1 & 25.2 & -19.5 \\
\hline 09Q1 & -43.1 & -24.4 & -22.3 & -27.4 & -30.1 & 0.6 & 7.6 & -32.8 & -19.3 & -29.6 & -33.4 \\
\hline $09 \mathrm{Q} 2$ & -46.3 & -9.9 & -25.8 & -20.8 & -16.7 & 0.1 & 19.9 & -15.7 & -30.2 & -45.5 & -21.2 \\
\hline 09Q3 & -41.5 & -2.9 & -27.9 & -15.3 & -12.1 & -1.9 & 2.9 & -9.2 & -31.8 & -51.7 & -15.2 \\
\hline 09Q4 & 6.9 & 31.6 & -21.6 & -0.1 & 11.8 & -4.2 & -2.4 & 22.5 & -19.1 & -36.4 & 1.3 \\
\hline
\end{tabular}

Source: Authors' calculations based on data from Statistics Singapore, http://www.singstat.gov.sg/.

To analyse the impact of the crisis on type of trade, we take China as a more detailed case study and discuss its trade performance in terms of processing and non-processing trade, and also trade by different type of enterprise. The processing trade accounts for a large share of several developing Asian countries including China, India, Vietnam, Malaysia and Indonesia. These countries are all host countries to FDI inflows and the endpoints of manufacturing chains for multinational enterprises. Although foreign-invested companies promote foreign trade for these countries, they also compete with local companies, especially with nationally-owned enterprises in China.

Proportion of China's processing trade and non-processing trade pre- and post-crisis are reported in Table 12 (these sum to a little less than one owing to small amounts of so-called special trade (gifts, for example)). These shares changed relatively little in the crisis. On the export side, shares of processing and non-processing trade were similar pre- and post-crisis, with processing the least at $43 \%$ and non-processing the most at $51 \%$ in January 2009. On the import side, non-processing trade was almost half of China's imports with a high of 54\% and a low of $48 \%$, whereas processing was over $30 \%$ of China's imports, with a high of $36 \%$ and 
a low of $30 \%$ during 2008 and 2009. The financial crisis seemingly did not affect China's processing trade pattern greatly.

Table 12: Proportionof Non-processing and Processing Trade for China During and After the 2008 Financial Crisis (\%)

\begin{tabular}{|c|c|c|c|c|c|c|c|c|}
\hline \multirow{3}{*}{$\begin{array}{l}\text { Item } \\
\text { Time } \\
\end{array}$} & \multicolumn{4}{|c|}{ Exports } & \multicolumn{4}{|c|}{ Imports } \\
\hline & \multicolumn{2}{|c|}{$\begin{array}{c}\text { Nonprocessing } \\
\text { Trade } \\
\end{array}$} & \multicolumn{2}{|c|}{ Processing Trade } & \multicolumn{2}{|c|}{$\begin{array}{c}\text { Nonprocessing } \\
\text { Trade }\end{array}$} & \multicolumn{2}{|c|}{ Processing Trade } \\
\hline & Y2008 & Y2009 & Y2008 & Y2009 & Y2008 & Y2009 & Y2008 & Y2009 \\
\hline Jan & 47.3 & 50.7 & 47.3 & 42.8 & 50.6 & 53.4 & 33.3 & 30.2 \\
\hline Feb & 43.3 & 39.3 & 51.5 & 53.3 & 49.9 & 52.6 & 34.5 & 31.8 \\
\hline Mar & 43.1 & 44.6 & 51.3 & 48.3 & 51.2 & 53.7 & 32.8 & 31.1 \\
\hline Apr & 46.0 & 45.3 & 48.0 & 47.6 & 51.2 & 54.2 & 33.0 & 31.0 \\
\hline May & 47.1 & 45.3 & 46.8 & 47.9 & 52.5 & 53.7 & 32.7 & 31.8 \\
\hline Jun & 47.9 & 43.7 & 46.1 & 49.4 & 51.3 & 54.0 & 32.7 & 30.2 \\
\hline Jul & 48.5 & 44.7 & 45.2 & 48.2 & 51.7 & 54.6 & 32.0 & 31.3 \\
\hline Aug & 48.6 & 44.2 & 45.2 & 48.7 & 50.7 & 53.4 & 32.6 & 33.0 \\
\hline Sep & 46.1 & 43.6 & 47.2 & 49.2 & 50.0 & 52.6 & 33.9 & 32.8 \\
\hline Oct & 44.5 & 41.5 & 48.5 & 51.6 & 48.0 & 51.4 & 36.1 & 34.5 \\
\hline Nov & 44.3 & 42.1 & 48.5 & 51.1 & 48.6 & 50.8 & 35.3 & 34.3 \\
\hline Dec & 48.4 & 44.0 & 43.7 & 48.5 & 49.7 & 52.8 & 33.0 & 31.8 \\
\hline
\end{tabular}

Note: Processing trade includes processing supplied materials and assembly of supplied parts, imported materials, and exported materials (outward processing). Non-processing trade is total trade apart from processing trade and special trade. Special trade includes materials for aid and donation, compensation trade, consignment trade, petty trade in the border areas, equipments imported for processing trade, export of goods for foreign contracted projects, leasing trade, imported equipment used as investment by foreign funded enterprises, barter transaction, duty-free commodities on payment of foreign currency; inbound and outbound goods in bonded warehouses, merchandise for transit in bonded warehouses, equipment imported in the export processing zones, etc. The total special trade is insignificant.

Source: Authors' calculations based on China Customs Statistics.

Table 13 reports growth rates of China's non-processing and processing trade compared with the same month in the previous year. On the export side, China's processing started to fall in November 2008, two months ahead of non-processing trade. Processing trade fell more rapidly than non-processing trade in the first quarter of 2009, and then the situation was reversed. On the import side, non-processing trade grew more quickly than processing trade before November 2008, then processing trade decreased more sharply than non-processing trade for a year. Processing trade then 
rebounded less strongly than non-processing trade at the end of 2009.

Table 13: Growth Rates of China's Non-processing and Processing Trade Pre- and Post-Crisis

(Compared with the same month in the previous year, \%)

\begin{tabular}{c|c|c|c|c||c|c|c|c}
\hline \multirow{2}{*}{ Item } & \multicolumn{4}{|c||}{ Exports } & \multicolumn{4}{c}{ Imports } \\
\cline { 2 - 9 } & \multicolumn{2}{|c|}{$\begin{array}{c}\text { Nonprocessing } \\
\text { Trade }\end{array}$} & \multicolumn{2}{c|}{ Processing Trade } & \multicolumn{2}{c}{$\begin{array}{c}\text { Nonprocessing } \\
\text { Trade }\end{array}$} & \multicolumn{2}{|c}{ Processing Trade } \\
\hline Time & Y2008 & Y2009 & Y2008 & Y2009 & Y2008 & Y2009 & Y2008 & Y2009 \\
\hline Jan & 33.1 & -11.7 & 18.3 & -25.4 & 42.0 & -39.9 & 11.7 & -48.3 \\
\hline Feb & 0.6 & -32.6 & 9.6 & -23.1 & 57.2 & -19.5 & 15.7 & -29.7 \\
\hline Mar & 48.9 & -14.2 & 16.0 & -22.0 & 42.0 & -21.3 & 11.1 & -28.9 \\
\hline Apr & 22.3 & -23.8 & 18.0 & -23.2 & 40.2 & -18.3 & 13.6 & -27.5 \\
\hline May & 29.8 & -29.2 & 23.6 & -24.7 & 66.8 & -23.3 & 17.3 & -27.0 \\
\hline Jun & 18.2 & -28.1 & 14.5 & -15.6 & 48.4 & -8.6 & 13.4 & -19.8 \\
\hline Jul & 31.8 & -28.9 & 20.9 & -17.7 & 55.7 & -10.0 & 12.1 & -16.9 \\
\hline Aug & 31.2 & -30.1 & 10.1 & -17.1 & 40.3 & -12.7 & 2.8 & -16.1 \\
\hline Sep & 29.5 & -19.6 & 11.0 & -11.4 & 38.8 & 1.2 & 3.0 & -7.1 \\
\hline Oct & 27.1 & -19.3 & 8.5 & -8.1 & 30.6 & -0.4 & 1.8 & -11.3 \\
\hline Nov & 4.3 & -6.0 & -11.1 & 4.3 & -13.1 & 31.9 & -25.5 & 22.8 \\
\hline Dec & 6.6 & 6.9 & -15.8 & 30.2 & -17.1 & 66.0 & -29.7 & 50.9 \\
\hline
\end{tabular}

Note: Processing trade includes processing supplied materials and assembly of supplied parts, imported materials, and exported materials (outward processing). Non-processing trade is total trade apart from processing trade and special trade. Special trade includes materials for aid and donation, compensation trade, consignment trade, petty trade in the border areas, equipments imported for processing trade, export of goods for foreign contracted projects, leasing trade, imported equipment used as investment by foreign funded enterprises, barter transaction, duty-free commodities on payment of foreign currency; inbound and outbound goods in bonded warehouses, merchandise for transit in bonded warehouses, equipment imported in the export processing zones, etc. The total special trade is insignificant.

Source: Authors' calculations based on China Customs Statistics.

As the majority of FDI inflows into Asian developing countries comes from American and European countries, most processing activities in these countries are completely or partly controlled by developed countries. Goods manufactured by them are mostly shipped back and sold in OECD markets. The trend of China's trade pattern in processing trade is consistent with the general trend in her trade with the US and the EU and reflects the impact of the recession in external markets on China's foreign trade. 
We also report changes in China's trade by different types of enterprise during the crisis. Shares of China's trade by type of enterprise are reported in Table 14. Foreign-invested enterprises always account for over half of China's total trade and this did not change markedly during the crisis. Both on the export and import sides, shares of national-owned enterprises decreased slightly and shares of private enterprises increased slightly after the crisis.

Table 14: Proportion Measured by Type of Chinese Enterprise During and Following the Crisis

\begin{tabular}{|c|c|c|c|c|c|c|}
\hline \multirow[b]{2}{*}{ Item } & \multicolumn{3}{|c|}{ Export } & \multicolumn{3}{|c|}{ Import } \\
\hline & $\begin{array}{l}\text { State- } \\
\text { owned }\end{array}$ & $\begin{array}{l}\text { Foreign- } \\
\text { invested }\end{array}$ & Private & $\begin{array}{l}\text { State- } \\
\text { owned }\end{array}$ & $\begin{array}{l}\text { Foreign- } \\
\text { invested }\end{array}$ & Private \\
\hline 08Mar & 17.5 & 59.1 & 23.4 & 31.8 & 54.1 & 14.1 \\
\hline 08Мау & 18.6 & 54.8 & 26.6 & 32.5 & 53.8 & 13.7 \\
\hline 08Jun & 18.3 & 54.7 & 26.9 & 32.5 & 54.4 & 13.2 \\
\hline 08Jul & 18.9 & 53.5 & 27.6 & 32.3 & 53.7 & 14.0 \\
\hline 08Aug & 18.5 & 53.9 & 27.6 & 31.9 & 52.5 & 15.6 \\
\hline 08Sep & 18.1 & 55.4 & 26.5 & 31.3 & 54.7 & 14.0 \\
\hline 08Oct & 17.0 & 56.4 & 26.6 & 30.2 & 56.4 & 13.5 \\
\hline 08Nov & 16.6 & 55.3 & 28.0 & 29.2 & 56.8 & 13.9 \\
\hline 08Dec & 17.6 & 52.6 & 29.9 & 28.0 & 56.3 & 15.8 \\
\hline 09Jan & 18.4 & 50.8 & 30.7 & 29.2 & 54.6 & 16.1 \\
\hline 09Feb & 17.5 & 60.0 & 22.5 & 27.9 & 55.6 & 16.6 \\
\hline 09Mar & 15.7 & 56.7 & 27.6 & 28.9 & 54.0 & 17.1 \\
\hline 09Apr & 16.5 & 54.7 & 28.8 & 28.8 & 53.8 & 17.4 \\
\hline 09May & 16.0 & 55.2 & 28.9 & 29.1 & 53.5 & 17.4 \\
\hline 09Jun & 16.3 & 55.7 & 28.0 & 28.2 & 54.4 & 17.4 \\
\hline 09Jul & 15.7 & 55.8 & 28.6 & 29.5 & 53.0 & 17.4 \\
\hline 09Aug & 15.7 & 55.5 & 28.8 & 29.5 & 53.2 & 17.3 \\
\hline 09Sep & 15.3 & 56.4 & 28.3 & 27.8 & 54.7 & 17.5 \\
\hline
\end{tabular}

Source: Authors' calculations based on China Customs Statistics.

Growth rates of China's trade by type of enterprise compared with the same month of the previous year are reported in Table 15. Exports by private enterprises grew the most in 2008 and decreased in 2009, with a two-month lag compared with nationally-owned and foreign-invested enterprises. Imports by nationally-owned enterprises grew the most before November 2008, and declined the fastest after that. Changes in China's processing trade are closely tied to changes in China's trade by type of enterprise. 
Table 15: Growth Rates of China's Trade by Type of Enterprise During and Following the Crisis (Compared with the same month in the previous year, \%)

\begin{tabular}{l|c|c|c||c|c|c}
\hline \multirow{2}{*}{ Item } & \multicolumn{3}{|c||}{ Exports } & \multicolumn{3}{c}{ Imports } \\
\cline { 2 - 6 } & $\begin{array}{c}\text { State- } \\
\text { owned }\end{array}$ & $\begin{array}{c}\text { Foreign- } \\
\text { invested }\end{array}$ & Private & $\begin{array}{c}\text { State- } \\
\text { owned }\end{array}$ & $\begin{array}{c}\text { Foreign- } \\
\text { invested }\end{array}$ & Private \\
\hline 08Mar & 30.7 & 21.2 & 62.6 & 41.1 & 15.4 & 31.8 \\
\hline 08May & 21.8 & 27.9 & 33.4 & 61.0 & 28.4 & 49.1 \\
\hline 08Jun & 12.4 & 19.6 & 16.7 & 49.1 & 23.4 & 29.7 \\
\hline 08Jul & 23.1 & 25.0 & 33.5 & 47.8 & 23.5 & 49.7 \\
\hline 08Aug & 21.9 & 15.7 & 32.5 & 39.7 & 9.2 & 52.4 \\
\hline 08Sep & 29.1 & 17.2 & 25.5 & 41.3 & 13.0 & 16.9 \\
\hline 08Oct & 15.8 & 14.3 & 33.3 & 31.4 & 7.7 & 20.2 \\
\hline 08Nov & -6.2 & -8.8 & 16.2 & -14.2 & -20.8 & -14.6 \\
\hline 08Dec & -4.3 & -10.9 & 17.7 & -23.7 & -21.9 & -12.5 \\
\hline 09Jan & -19.9 & -23.2 & -4.1 & -45.8 & -43.4 & -35.7 \\
\hline 09Feb & -26.8 & -24.7 & -27.6 & -33.2 & -23.0 & -3.3 \\
\hline 09Mar & -25.7 & -20.5 & -2.4 & -31.7 & -25.0 & -9.4 \\
\hline 09Apr & -28.9 & -24.5 & -14.0 & -28.5 & -24.9 & -1.7 \\
\hline 09May & -36.8 & -25.9 & -20.0 & -32.8 & -25.4 & -4.8 \\
\hline 09Jun & -30.2 & -19.8 & -18.1 & -24.6 & -13.2 & 14.9 \\
\hline 09Jul & -36.1 & -19.5 & -20.1 & -22.2 & -15.9 & 5.7 \\
\hline 09Aug & -34.9 & -20.8 & -19.7 & -23.4 & -15.9 & -8.3 \\
\hline 09Sep & -28.1 & -13.5 & -9.2 & -14.6 & -3.9 & 20.5 \\
\hline
\end{tabular}

Source: Authors' calculations based on China Customs Statistics. 


\section{The Trade Compression in Asia during the Financial Crisis, the 1930s and the Asian Financial Crisis}

Comparing trade performance with earlier crises is complex and inevitably involves inexact comparisons. For the 1930s we compare both North American and European trade impacts as well as Asian, since in the 1930s Asian trade was insignificant except for Japan (and to a lesser extent China). We use Japan (the worst trade performer among these Asian countries) and China (the average trade performer) for examples of trade in the Great Depression of the 1930s. The annual growth rates of trade are presented in Table 16. China's export and import growth rates declined from $26 \%$ and $21 \%$ to $17 \%$ and $19 \%$ between 2007 and 2008 , then experienced $-16 \%$ and $-12 \%$ negative growth in 2009, respectively. Exports by Japan grew by $11.5 \%$ in 2007 , then fell slightly in 2008 and sharply by $33 \%$ in 2009. Japanese imports reversed a trend of steady growth and declined by $35 \%$ in 2009 .

The comparison with the 1930 s is striking. During the Great Depression, US trade experienced the shortest recession period of all the major economies; three years, far shorter than that of other countries. French trade experienced the longest recession with exports experiencing negative growth each year between 1927 and 1936 and imports falling sharply between 1930 and 1935. On both export and import sides, the trade of the US, Germany, France, and China fell sharply during 1930 and 1932. Either because of the magnitude of the drop, or the length of the Depression, the US, Germany, France and China experienced a significantly deeper trade compression in the Great Depression than China and Japan in this financial crisis.

GDP growth rate comparisons for China and Japan pre- and post-financial crisis and in the 1930s are also striking. The average annual GDP growth for China between 2007 and 2009 remained high whereas Japan's GDP growth rate fell from 2\% to $-0.7 \%$. During the 1930s, US annual GDP growth rates between 1930 and 1935 were $-8.6 \%$, $-6.5 \%,-13.1 \%,-1.3 \%$ and 10.9 respectively (Maddison, 1997), whereas China's GDP growth rates between 1932 and 1936 were $3.68 \%,-0.72 \%,-8.64 \%, 8.30 \%$, and $5.87 \%$ 
respectively (Yeh, 1977). Japan's strong growth performance of 3.7\% during the Great Depression was higher than China's (average 1.7\%) (Maddison, 1997). These data suggest that the impact of the 1930s Depression on real GDP was significantly smaller than that on trade in the Asian countries and trade rebounded more strongly than GDP after the crisis.

Table 16: Comparison of Annual Growth Rates of Trade in the 2008 Crisis with the 1930s Depression (year-on-year, \%)

\begin{tabular}{|c|c|c|c|c|c|c|c|c|c|c|c|c|c|}
\hline \multicolumn{5}{|c|}{ 2010's } & \multicolumn{9}{|c|}{ 1930's } \\
\hline & \multicolumn{2}{|c|}{ Exports } & \multicolumn{2}{|c|}{ Imports } & & \multicolumn{4}{|c|}{ Exports } & \multicolumn{4}{|c|}{ Imports } \\
\hline Year & $\mathbf{C N}$ & JP & $\mathbf{C N}$ & JP & Year & $\mathrm{CN}$ & US & GMY & FRC & $\mathbf{C N}$ & US & GMY & FRC \\
\hline 2007 & 25.7 & 11.5 & 20.8 & 8.6 & 1928 & NA & 5.4 & 13.6 & -6.5 & NA & -2.2 & -1.6 & 0.7 \\
\hline 2008 & 17.2 & -3.5 & 18.5 & 8.0 & 1929 & NA & 2.2 & 9.0 & -2.4 & NA & 7.5 & -4.0 & 9.0 \\
\hline 2009 & -16 & -33.1 & -11.2 & -34.8 & 1930 & -11.8 & -26.7 & -10.5 & -12.5 & 6.4 & -30.4 & -22.7 & -9.8 \\
\hline 2010 & $20.7^{\mathrm{E}}$ & $20.5^{\mathrm{E}}$ & $18.7^{\mathrm{E}}$ & $11.5^{\mathrm{E}}$ & 1931 & -3.1 & -36.9 & -18.7 & -30.6 & 16.2 & -31.7 & -35.3 & -19.6 \\
\hline \multicolumn{5}{|c|}{ Growth Rate of GDP } & 1932 & -37.8 & -33.6 & -38.3 & -35.3 & -23.9 & -36.7 & -30.6 & -29.4 \\
\hline & 2007 & 2008 & 2009 & 2010 & 1933 & 7.6 & 4.0 & -14.2 & -6.3 & -11.7 & 9.6 & -9.9 & -4.6 \\
\hline $\mathrm{CN}$ & 13.4 & 9.0 & 8.7 & $9.1^{\mathrm{E}}$ & 1934 & -12.6 & 27.3 & -14.4 & -3.4 & -23.4 & 14.2 & 5.9 & -18.8 \\
\hline JP & 2.2 & 2.0 & -0.7 & $-5.7^{\mathrm{E}}$ & 1935 & 7.7 & 7.0 & 1.0 & -13.2 & -10.8 & 23.7 & -8.3 & -9.2 \\
\hline
\end{tabular}

Key: CN - China, JP - Japan, US - United States, GMY - Germany, FRC - France.

Source: Authors' calculations. China's trade between 2007 and 2009 based on China Customs Statistics. China's GDP growth rate is from the Bureau of Statistics of China. Japan GDP growth rates are from the Index of Mundai. Data for China's trade and GDP forecast for 2010 are from Analysis and Forecast of China's Economic Situation (Economic Blue Book, Autumn 2010). Data for Japan between 2007 and 2009 are based on Trade Statistics of Japan. The forecast for 2010 for Japan is from Forecast for the Japanese Economy in Fiscal 2010 and 2011 by Mitsubishi UFJ Research and Consulting. Estimation of Japan trade for 2010 includes trade in service. Data for the US, Germany and France in the Great Depression come from the NBER Macrohistory Database.

We also present quarterly growth rates of Chinese and Japanese trade (compared with the previous quarter). Trade performance during this financial crisis and OECD countries' trade performance during the Great Depression are also reported in Table 17. The trade of Japan and China fell proportionately more in the first quarter of 2009 than for OECD countries in the initial years of the Great Depression, but the trade of Japan and China in the financial crisis shrank less than three quarters before rebounding quickly. 
Table 17: Quarterly Growth Rates of Trade of China and Japan in the 2008 Crisis and OECD Economies in the 1930' Depression (Compared with the previous quarter, \%)

\begin{tabular}{|c|c|c|c|c|c|c|c|c|c|}
\hline & \multicolumn{2}{|c|}{ China } & & \multicolumn{3}{|c|}{ Export } & \multicolumn{3}{|c|}{ Import } \\
\hline & Exports & Imports & & US & GMY & FRC & US & GMY & FRC \\
\hline 2008Q1 & -10.0 & 0.5 & 1929Q1 & -9.6 & -6.9 & -13.3 & 9.9 & -2.4 & 3.2 \\
\hline 2008Q2 & 17.8 & 14.6 & 1929Q2 & -15.2 & 13.6 & 6.2 & 3.8 & 3.2 & 0.8 \\
\hline 2008Q3 & 13.2 & 7.4 & 1929Q3 & 1.4 & 0.4 & -3.5 & -7.8 & -3.6 & -13.7 \\
\hline 2008Q4 & -13.1 & -26.3 & 1929Q4 & 14.5 & -0.9 & 6.9 & -3.2 & -1.5 & 8.4 \\
\hline 2009Q1 & -30.7 & -23.7 & 1930Q1 & -19.2 & -6.7 & -11.0 & -14.1 & -3.6 & -2.5 \\
\hline 2009Q2 & 12.4 & 31.8 & 1930Q2 & -16.2 & -7.7 & -6.4 & -5.6 & -20.1 & -8.4 \\
\hline 2009Q3 & 17.7 & 18.7 & 1930Q3 & -7.4 & -1.2 & 0.9 & -21.0 & -3.7 & -3.4 \\
\hline 2009Q4 & 9.2 & 2.7 & 1930Q4 & 1.6 & -1.2 & -7.8 & -0.9 & -7.8 & 7.4 \\
\hline \multirow[t]{6}{*}{ 2010Q1 } & 28.7 & 64.7 & 1931Q1 & -20.3 & -16.6 & -17.6 & -13.9 & -14.7 & -11.2 \\
\hline & & & 1931Q2 & -14.6 & -1.8 & -6.7 & -5.2 & -1.8 & -3.5 \\
\hline & & & 1931Q3 & -13.3 & 6.5 & -8.5 & -5.1 & -22.3 & -10.7 \\
\hline & & & $1931 \mathrm{Q} 4$ & 10.8 & -3.1 & -1.6 & -7.7 & -0.4 & -13.1 \\
\hline & \multicolumn{2}{|c|}{ Japan } & 1932Q1 & -21.2 & -31.8 & -24.9 & -15.7 & -14.7 & -16.7 \\
\hline & Exports & Imports & $1932 \mathrm{Q} 2$ & -17.0 & -13.9 & -9.6 & -12.2 & -8.3 & 7.1 \\
\hline 2008Q1 & -5.2 & -2.1 & 1932Q3 & -8.8 & -3.8 & -6.3 & -23.0 & -7.4 & -12.8 \\
\hline 2008Q2 & -1.0 & 4.2 & 1932Q4 & 21.9 & 11.2 & 14.6 & 14.2 & 15.4 & 12.0 \\
\hline 2008Q3 & 5.7 & 11.2 & 1933Q1 & -22.1 & -17.8 & -11.3 & -10.6 & -11.8 & 1.5 \\
\hline 2008Q4 & -22.5 & -20.2 & 1933Q2 & 2.8 & -0.2 & -3.3 & 15.6 & -6.1 & -6.6 \\
\hline 2009Q1 & -34.4 & -31.6 & 1933Q3 & 28.4 & 3.5 & 2.2 & 40.0 & 3.3 & -10.8 \\
\hline 2009Q2 & 14.5 & -0.8 & 1933Q4 & 30.8 & 2.8 & 11.0 & -7.1 & 2.8 & 4.7 \\
\hline 2009Q3 & 12.9 & 11.9 & 1934Q1 & -7.7 & -13.4 & -9.7 & 3.3 & 6.9 & -2.4 \\
\hline 2009Q4 & 8.6 & 4.4 & 1934Q2 & -3.0 & -9.3 & -4.7 & 2.5 & 0.5 & -10.7 \\
\hline 2010Q1 & 2.1 & 2.6 & 1934Q3 & 2.9 & 1.4 & -0.8 & -13.4 & -8.3 & -15.2 \\
\hline & & & 1934Q4 & 8.9 & 7.0 & 11.8 & 9.1 & 3.5 & 8.5 \\
\hline
\end{tabular}

Key: US - United States, GMY - Germany, FRC - France.

Source: Authors' calculations. China's trade between 2007 and 2009 based on China Customs Statistics. China's GDP growth rate is from the Bureau of Statistics of China. Japan GDP growth rates are from the Index of Mundai. Data for China's trade and GDP forecast for 2010 are from Analysis and Forecast of China's Economic Situation (Economic Blue Book, Autumn 2010). Data for Japan between 2007 and 2009 are based on Trade Statistics of Japan. The forecast for 2010 for Japan is from Forecast for the Japanese Economy in Fiscal 2010 and 2011 by Mitsubishi UFJ Research and Consulting. Estimation of Japan trade for 2010 includes trade in service. Data for the US, Germany and France in the Great Depression come from the NBER Macrohistory Database.

In the 1930s OECD countries suffered years of decline before recovery; if we compare the proportional decline in individual quarters, the trade of Japan and China fell more in the first quarter of 2009 than OECD countries in the 1930s. Yet the proportion of decline during the crisis is significantly more than the shrinkage of 
Chinese and Japanese trade in the 1930s. For the OECD the fall is smaller. Therefore, the initial impact of the recent financial crisis on the trade of Japan and China is more severe than the impact of the Great Depression, but the duration of the impact is shorter.

We also report data on Asian economies' performance during the Asian financial crisis and make comparisons with trade performance in the crisis. The yearon-year growth rates of exports of Asian economies during the Asian financial crisis are reported in Table 18. Exports by China and Vietnam retained positive growth between 1996 and 2003 whereas others experienced a fall, but at most for two years. The biggest annual proportional trade decline among other Asian economies was 17\%, but this is significantly less than exports of Japan, the Philippines and Taiwan in 2009. Thailand and Indonesia, who suffered the severest recession during the Asian financial crisis, found their exports only declined $6.9 \%$ and $4.6 \%$ in 1998 respectively, but they dropped about $15 \%$ in 2009. Exports of Singapore declined the most among these economies, with a fall of $15.7 \%$ in 1998, and exports of Taiwan, Japan and the Philippines fell by over $16 \%$ in 2001 . Among these economies, only the exports of Korea performed better in 2009 than in the Asian financial crisis. Thus, in general, the impacts of the recent crisis on the exports of the Asian economies are more severe than the impacts of the Asian financial crisis.

Table 18: Export Growth Rates of Key Asian Economies before and after the Asian Financial Crisis (Year-on-year, \%)

\begin{tabular}{c|c|c|c|c|c|c|c|c|c|c|c}
\hline & CN & ID & IN & JP & KR & MY & PH & SG & TH & CT & VN \\
\hline 1996 & 17.9 & 5.8 & 8.0 & -6.6 & 4.1 & 7.3 & 17.7 & 6.7 & -1.9 & 3.7 & NA \\
\hline 1997 & 20.9 & 12.2 & 5.8 & 2.2 & 6.7 & 0.7 & 22.8 & 0.8 & 4.1 & 5.6 & 26.6 \\
\hline 1998 & 0.5 & -10.5 & -4.6 & -8.6 & -4.7 & -7.3 & 16.9 & -15.7 & -6.9 & -9.3 & 1.9 \\
\hline 1999 & 6.1 & 1.7 & 8.2 & 7.9 & 9.9 & 17.0 & 16.1 & 6.1 & 7.6 & 9.9 & 23.3 \\
\hline 2000 & 27.9 & 27.6 & 17.3 & 13.8 & 21.2 & 17.0 & 9.1 & 20.5 & 19.6 & 22.8 & 25.2 \\
\hline 2001 & 6.8 & -12.3 & 3.6 & -16.5 & -14.0 & -10.6 & -16.2 & -10.8 & -7.1 & -16.9 & 4.0 \\
\hline 2002 & 22.4 & 3.1 & 14.2 & 3.1 & 7.9 & 6.1 & 9.9 & 3.0 & 4.7 & 7.1 & 11.2 \\
\hline 2003 & 34.6 & 8.4 & 19.1 & 13.5 & 20.7 & 12.4 & 2.7 & 14.9 & 18.2 & 11.3 & 20.6 \\
\hline 2009 & -16 & -15 & $-4.7 *$ & -33.1 & 9.8 & -15.5 & -21.9 & -18 & -14.2 & -20.3 & -9.7 \\
\hline
\end{tabular}

Key: CN - China, ID - Indonesia, IN - India, JP - Japan, KR - Korea, MY - Malaysia, PH Philippines, SG - Singapore, TH - Thailand, CT - Chinese Taiwan, VN - Vietnam. 
Source: Authors' calculations. Taiwanese data are based on Taiwan Statistics Yearbook 2008. Others are based on data from World Development Indicators of the World Bank.

The year--on-year growth rates of imports by Asian economies during the Asian financial crisis are reported in Table 19. Except for China, imports kept growing with Vietnam's imports experiencing only a slight decline in 1998. Other countries' imports experienced severe decline during the recent financial crisis. Imports of China, India, Japan, Philippine, Taiwan and Vietnam dropped more in 2009 than in 1998, and imports by Indonesia, Korea, Malaysia and Thailand dropped less in 2009 than in 1998. World oil prices dropped about $40 \%$ in 2008 , but dropped from $\$ 137.1$ per barrel in July 2008 to $\$ 34.6$ per barrel in January 2009, a 75\% fall (EIA). Even excluding the impact of the oil price changes, the impact of the financial crisis on Asian imports is still more severe than that of the Asian financial crisis.

Table 19: Import Growth Rates of Asian Economies before and after the Asian Financial Crisis

\begin{tabular}{c|c|c|c|c|c|c|c|c|c|c|c}
\hline & CN & ID & IN & JP & KR & MY & PH & SG & TH & CT & VN \\
\hline 1996 & 19.5 & 8.1 & 15.4 & 6.7 & 12.2 & 1.8 & 20.8 & 6.5 & 0.8 & -1.0 & NA \\
\hline 1997 & 3.7 & 4.5 & 4.4 & -2.9 & -2.2 & 1.2 & 14.0 & 1.2 & -13.8 & 11.7 & 4.0 \\
\hline 1998 & 0.3 & -30.9 & -2.0 & -18.2 & -36.2 & -26.5 & -18.8 & -21.0 & -33.7 & -8.5 & -0.8 \\
\hline 1999 & 15.9 & -4.2 & 1.6 & 11.4 & 29.1 & 13.0 & 36.2 & 7.5 & 17.1 & 5.7 & 2.1 \\
\hline 2000 & 35.2 & 31.9 & 27.8 & 22.3 & 36.2 & 26.3 & 7.7 & 23.0 & 31.4 & 26.6 & 33.2 \\
\hline 2001 & 8.1 & -14.1 & -2.4 & -8.6 & -13.4 & -10.3 & -13.3 & -14.2 & -2.9 & -23.3 & 3.4 \\
\hline 2002 & 21.3 & 2.8 & 6.8 & -3.7 & 7.7 & 8.1 & 6.3 & 2.2 & 4.5 & 4.9 & 22.1 \\
\hline 2003 & 39.8 & 10.9 & 24.4 & 13.6 & 18.0 & 5.4 & 3.1 & 8.5 & 17.4 & 13.0 & 28.0 \\
\hline 2009 & -11.2 & -25 & $-8.2 *$ & -34.8 & -12.4 & -16.6 & -24.2 & -21 & -22.6 & -27.5 & -14.7 \\
\hline
\end{tabular}

Key: CN - China, ID - Indonesia, IN - India, JP - Japan, KR - Korea, MY - Malaysia, PH Philippines, SG - Singapore, TH - Thailand, CT - Chinese Taiwan, VN - Vietnam.

Source: Authors' calculations. Data for Taiwan are based on Taiwan Statistics Yearbook 2008. Others are based on from World Development Indicators of the World Bank.

Finally we present data in Table 20 on annual growth rates of key Asian economies before and after the Asian financial crisis and compare them with data for the recent financial crisis. China, India and Vietnam kept growing rapidly during both financial crises. China and Vietnam lost 1.5 points and 2.4 points of GDP growth in 1998, whereas they lost 4.0 and 2.3 points of GDP growth in 2008. Indonesia and Thailand experienced declines of over 10\% in GDP in 1998, whereas Indonesia's GDP 
increased by $4.5 \%$ and Thailand declined by $2.3 \%$ in 2009 . GDP for Korea and the Philippines kept growing between 2007 and 2009, although it declined by $6.9 \%$ and $0.6 \%$ respectively in 1998. GDP growth rates of Taiwan are positive between 1996 and 2000, but dropped to -2.2 in 2001 then rebounded. GDP growth rates for Taiwan dropped from $5.7 \%$ in 2007 to $-2.5 \%$ in 2009. GDP of Japan and Singapore declined mildly at $-2.0 \%$ and $-1.4 \%$ respectively. GDP growth rates of Singapore have fluctuated substantially over the last two decades. They dropped from $8.3 \%$ to $-1.4 \%$ between 1997 and 1998 and from 7.8\% to 1.1\% between 2007 and 2008 .

Thus, in general, the Asian financial crisis affected the Asian economies more severely in terms of GDP growth than the recent financial crisis, but the trade impacts were greater. Green (2010) also analyses Asia's policy response to the 2008 crisis using ASEAN economies as an example, and argues that south-east Asia was slow to mobilize to reduce the impact of the crisis. Fiscal expenditure policy delayed stimulating domestic demand and mitigating the impact on the poor (see also Athukorala \& Chongvilaivan, 2010; Basri \& Rahardja, 2010).

Table 20: Real GDP Growth Rates of Asian Economies Pre- and Post-Financial Crises

\begin{tabular}{l|c|c|c|c|c|c|c|c|c|c|c}
\hline \multicolumn{10}{c}{ Year-on-year, \%) } \\
\hline 1996 & CN & ID & IN & JP & KR & MY & PH & SG & TH & CT & VN \\
\hline 1997 & 9.3 & 4.7 & 4.5 & 1.6 & 4.7 & 7.3 & 5.2 & 8.3 & -1.4 & 6.6 & 8.2 \\
\hline 1998 & 7.8 & -13.1 & 6.0 & -2.0 & -6.9 & -7.4 & -0.6 & -1.4 & -10.5 & 4.5 & 5.8 \\
\hline 1999 & 7.6 & 0.8 & 7.1 & -0.1 & 9.5 & 6.1 & 3.4 & 7.2 & 4.4 & 5.7 & 4.8 \\
\hline 2000 & 8.4 & 4.9 & 4.0 & 2.9 & 8.5 & 8.9 & 6.0 & 10.1 & 4.8 & 5.8 & 6.8 \\
\hline 2001 & 8.3 & 3.6 & 5.2 & 0.2 & 4.0 & 0.5 & 1.8 & -2.4 & 2.2 & -2.2 & 6.9 \\
\hline 2002 & 9.1 & 4.5 & 3.8 & 0.3 & 7.2 & 5.4 & 4.4 & 4.1 & 5.3 & 4.6 & 7.1 \\
\hline 2003 & 10.0 & 4.8 & 8.4 & 1.4 & 2.8 & 5.8 & 4.9 & 3.8 & 7.1 & 3.5 & 7.3 \\
\hline 2007 & 13.0 & 6.3 & 9.1 & 2.4 & 5.1 & 6.3 & 7.2 & 7.8 & 4.9 & 5.7 & 8.5 \\
\hline 2008 & 9.0 & 6.0 & 7.3 & 0.4 & 2.2 & 4.5 & 4.6 & 1.1 & 4.8 & 0.12 & 6.2 \\
\hline $2009^{\mathrm{E}}$ & 8.7 & 4.5 & 7.2 & -0.7 & 0.2 & -1.7 & 0.9 & -2.1 & -2.3 & -2.5 & 5.3 \\
\hline
\end{tabular}

Key: CN - China, ID - Indonesia, IN - India, JP - Japan, KR - Korea, MY - Malaysia, PH Philippines, SG - Singapore, TH - Thailand, CT - Chinese Taiwan, VN - Vietnam.

Source: Taiwanese data are taken from Taiwan Statistical Yearbook 2008. Others are taken from the United Nations Statistics.

The impacts of the recent financial crisis on Asian countries' trade thus seem 
significantly milder than the impacts of the Great Depression on the trade of OECD countries, but impacts of the Asian financial crisis on the trade of Asian countries were more severe. In terms of GDP growth, the impacts of the financial crisis seem less pronounced than those of the Asian financial crisis on the Asian economies. 


\section{Conclusion}

In this paper we document and compare the trade performance of the major Asian economies both during and following the 2008 financial crisis. We present data for China, India, Thailand, Malaysia, Korea, Japan, Singapore and Taiwan on both the import and export sides on a monthly basis throughout the crisis. We compare their trade performance in aggregate and by product and bilateral trading partner. Except for Korea, which experienced an initial smaller impact but a quick rebound, Asian economies experienced considerable declines in trade in the whole of 2009. In general, imports dropped more proportionally than exports for these economies, which reflects both the consequences of oil price fluctuations and the impacts of the financial crisis on the real economies in the OECD. For Asia, on both the export and import sides, there is a solid rebound in 2010 .

We also make comparisons of the impact of the recent financial crisis on Asian trade with both the Great Depression in China and Japan and the Asian financial crisis of 1998. The impact on Asian trade between 2008 and 2009 is milder than for OECD countries during the Great Depression and more severe than for Asian countries during the Asian financial crisis. For GDP growth rates, Asian countries' impacts are greater and declined more in the Asian financial crisis than between 2008 and 2009. 


\section{Bibliography}

Athukorala, P. \& Chongvilaivan, A. (2010) "The Global Financial Crisis and Asian Economies: Impact and Trade Policy Response" [J]. ASEAN Economic Bulletin, 27(1), pp1-4.

Baldwin, R. (2009) "The great trade collapse: What caused it and what does it mean?"[R], VoxEU.org working paper, 27 November 2009, [Online] Available from: http://www.voxeu.org/index.php?q=node/4304, [Accessed $29^{\text {th }}$ April 2010].

Bank of Thailand: International Trade Statistics, [Online] Available from: http://www.bot.or.th/English/Statistics/EconomicAndFinancial/ExternalSector/Pages/St atInternationalTrade.aspx, [Accessed $4^{\text {th }}$ April 2010].

Basri, M. C. \& Rahardja, S. (2010) "The Indonesian Economy amidst the Global Crisis: Good Policy and Good Luck"[J], ASEAN Economic Bulletin, 27(1), pp77-97.

Bureau of Foreign Trade of Taiwan: Foreign Trade Statistics [Online] Available from: http://cus93.trade.gov.tw/FSCI/, [Accessed 25 ${ }^{\text {th }}$ March 2010].

China Customs Statistics: China Custom Monthly Report March 2008 - April 2010, [Online] Available from: http://www.haiguan.info, [Accessed $6^{\text {th }}$ May 2010].

Chinese Academy of Social Science (2010), Analysis and Forecast of China's Economic Situation (Economic Blue Book, Autumn 2010)[M], Beijing, China, Chinese Social Science Press.

Green, D. J. (2010) "Southeast Asia's Policy Response to the Global Economic Crisis"[J]. ASEAN Economic Bulletin, 27(1), pp5-26.

Gregory, R. Henn, C. McDonald, B. \& Saito, M. (2010) "Trade and the Crisis: Protect or Recover"[R], IMF SPN 1007, [Online] Available from:

http://www.imf.org/external/pubs/ft/spn/2010/spn1007.pdf, [Accessed $20^{\text {th }}$ May 2010].

Huh, C. \& Nam, K. (2010) "A Preview of Tale of Korea's Two Crises: Distinct Aftermath of 1997 and 2008 Crises"[J]. The Journal of the Korean Economy, pp1-30.

Index of Mundi: , [Online] Available from:

http://www.indexmundi.com/japan/gdp_real_growth_rate.html, [Accessed $8^{\text {th }}$ May 2010].

Korean Customs Statistics, [Online] Available from: http://english.customs.go.kr/kcs web/user.tdf, [Accessed $6^{\text {th }}$ April 2010].

Maddison, A. (1997) Review of World Economy in Past Two Hundred Years[M].

Reform Press, Beijing, China.

Ministry of Commerce \& Industry of India: DGCI\&S (Directorate General of Commercial Intelligence and Statistics) Database, [Online] Available from: http://www.dgciskol.nic.in/, [Accessed 29 ${ }^{\text {th }}$ March 2010].

Taiwan Statistical Yearbook 2008, [Online] Available from: 
http://eng.dgbas.gov.tw/lp.asp?CtNode $=2351 \& \mathrm{CtUnit}=1072 \&$ BaseDSD $=36 \& \mathrm{mp}=2$, [Accessed 20 ${ }^{\text {th }}$ April 2010].

Trade Statistics of Japan: Ministry of Finance of Japan, [Online] Available from: http://www.customs.go.jp/toukei/info/tsdl_e.htm, [Accessed $2^{\text {nd }}$ April 2010].

Mitsubishi UFJ Research and Consulting, "Forecast for the Japanese Economy in Fiscal 2010 and 2011"[R], [Online] Available from:

http://www.murc.jp/english/publ/forecast/2010/201002.pdf, [Accessed 16 ${ }^{\text {th }}$ April 2010].

National Bureau of Statistics of China: China Statistical Yearbook 1996-2009, [O nline] Available from: http://www.stats.gov.cn/english/statisticaldata/yearlydata/, [Ac cessed 25 ${ }^{\text {th }}$ April 2010].

NBER Macrohistory database, [Online] Available from: http://www.nber.org/databas es/macrohistory/contents/chapter07.html, [Accessed 10 ${ }^{\text {th }}$ April 2010].

OECD Statistics, [Online] Available from: http://stats.oecd.org/, [Accessed $14^{\text {th }}$ April 2010].

Official Portal of Ministry of International Trade and Industry of Malaysia, International Trade Statistics, , [Online] Available from: http://www.miti.gov.my/, [Accessed $6^{\text {th }}$ April 2010].

Statistics Singapore, [Online] Available from:

http://www.singstat.gov.sg/pubn/catalogue.html, [Accessed $2^{\text {nd }}$ April 2010].

UNCTAD: International Merchandise Trade Database, [Online] Available from: htt p://www.unctad.org/Templates/Page.asp?intItemID=1890\&lang=1, [Accessed 18th May 2010].

United Nations Statistics, [Online] Available from:

http://unstats.un.org/unsd/snaama/downloads/Download-GDPgrowth-USD-all.xls, [Accessed 11 ${ }^{\text {st }}$ April 2010].

US Energy Information Administration, [Online] Available from: http://www.eia.doe.gov/dnav/pet/hist/LeafHandler.ashx?n=PET\&s=WTOTWORLD\&f $=\mathrm{W}$. [Accessed 24 ${ }^{\text {th }}$ May 2010].

Wang, J. \& Whalley, J. (2010) China's Trade and Investment with the South Pre and Post the Crisis[R]. Paper prepared at World Bank Conference on Trade and the Impacts of the Financial Crisis on Asia, May 102010.

World Development Indicators of theWorld Bank, [Online] Available from: http://data.worldbank.org/data-catalog, [Accessed 16th April 2010].

WTO, 2010 Press Releases No. 598, 26 March 2010, "World Trade 2009, Prospects For 2010: Trade to Expand by $9.5 \%$ in 2010 after a Dismal 2009, WTO reports"[N] [Online] Available from: http://www.wto.org/english/news_e/pres10_e/pr598_e.pdf. [Accessed 21 ${ }^{\text {st }}$ April 2010]. 
WTO, 2010 Press Releases No. 604, 2 June 2010, First Quarter of 2010 Sees Trade Value Rise by about $25 \%$ [N], [Online] Available from:

http://www.wto.org/english/news_e/pres10_e/pr604_e.htm [Accessed $3^{\text {rd }}$ June 2010].

Yeh, K.C. (1977) "China's National Income, 1931-1936" In Modern Chinese Economic History, The Institute of Economics, Academia Sinica. 